\title{
INTERVEÇÕES HUMANITÁRIAS: RESPONSABILIDADE DE PROTEGER?
}

Trabalho de Conclusão de Curso de Especialização em Relações Internacionais do Instituto de Relações Internacionais da Universidade de Brasília, apresentado como requisito parcial à obtenção do título de Especialista em Relações Internacionais

Orientador: Prof. Dr. Eitii Sato

\section{BRASÍLIA}




\section{FICHA CATALOGRÁFICA}

BASTOS, Carla Lima.

Responsabilidade de proteger

Carla Lima Bastos; Orientador: Eitii Sato. — Brasília, 2008

p.

Trabalho de Conclusão de Curso. Instituto de Relações Internacionais/Universidade de Brasília.

Curso de Especialização em Relações Internacionais

1. Intervenções humanitárias; 2. Responsabilidade de proteger; 3. Soberania como responsabilidade.

Instituto de Relações Internacionais 
Aos meus pais pelo amor e apoio incondicionais. 


\section{AGRADECIMENTOS}

Ao orientador Prof. Dr. Eitii Sato pela atenção e incentivo.

Aos meus pais pelo incansável apoio.

Aos meus amigos que, de alguma forma, colaboraram na produção deste trabalho. 


\section{RESUMO}

O presente estudo tem por objetivo analisar o relatório Responsabilidade de Proteger elaborado pela Comissão Internacional sobre Intervenções e Soberania Estatal. Busca-se, inicialmente apresentar um histórico das teses em favor das intervenções humanitárias. Em seguida, procura-se analisar os fundamentos, apresentados pelo relatório Responsabilidade de Proteger, que justificariam a implementação de intervenções militares para fins humanitários. Ao final, são examinados alguns pontos controversos do relatório.

Palavras-chave: Intervenções humanitárias - Responsabilidade de proteger Soberania como responsabilidade. 


\begin{abstract}
This study seeks to analyze the report Responsibility to Protect, produced by the International Commission on Intervention and State Sovereignty. It aims, initially, to present a historical background on the theses in favor of humanitarian interventions. After that, it seeks to examine the arguments, offered by the report Responsibility to Protect, that would justify the use of military interventions with humanitarian ends. At the end, some controversial aspects of the report are analyzed.
\end{abstract}

Keywords: Humanitarian Interventions - Responsibility to Protect Sovereignty as responsibility. 


\section{SUMÁRIO}

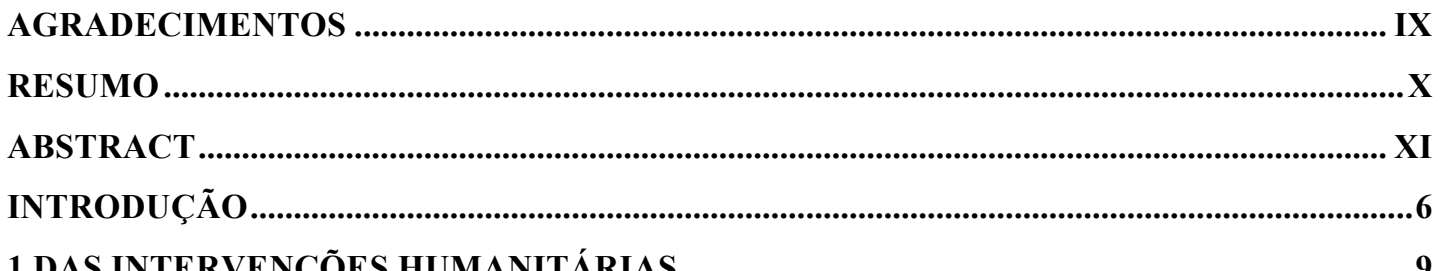

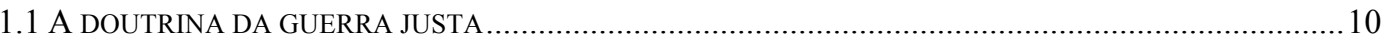

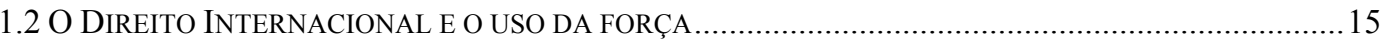

1.3 O DOUTRINA CONTEMPORÂNEA DAS INTERVENÇÕES HUMANITÁRIAS .....................................18

1.3.1 Fundamentos normativos à intervenção humanitária .....................................................19

1.3.1.1 Interpretações do artigo 2.4 da Carta das Nações Unidas ..............................................................19

1.3.1.2 Intervenção humanitária como direito internacional consuetudinário ………………………….....22

1.3.2 Fundamentos morais à intervenção humanitária ………………………………..........2. 24

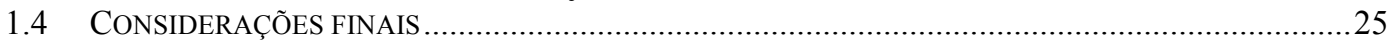

2 RESPONSABILIDADE DE PROTEGER ……………..............................................................26

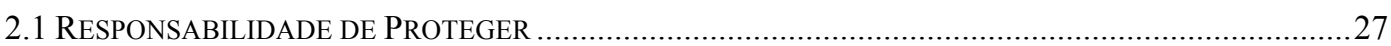

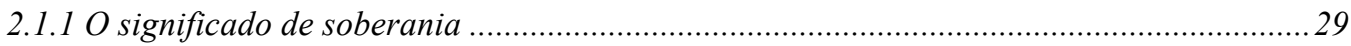

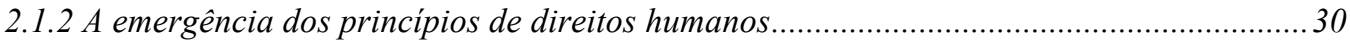

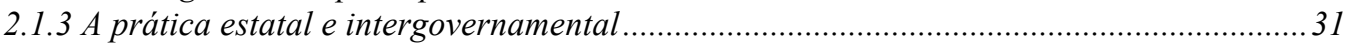

2.2 DIREITO DE INGERÊNCIA VERSUS RESPONSABILIDADE DE PROTEGER ……......................................32

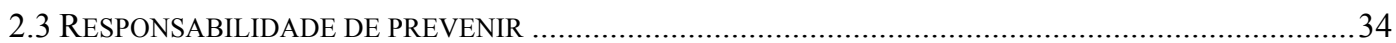

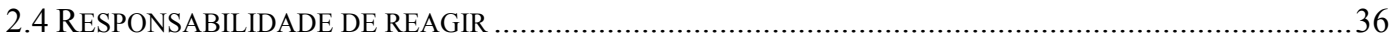

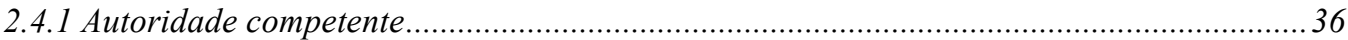

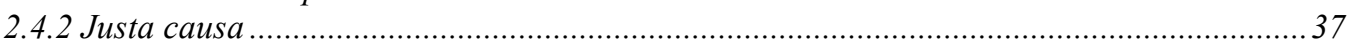

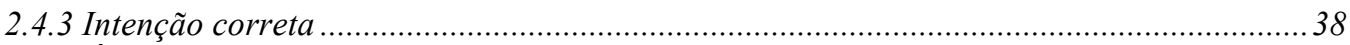

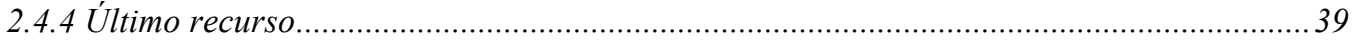

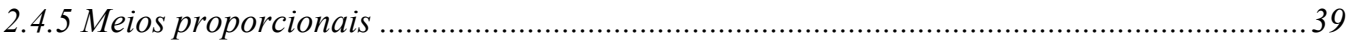

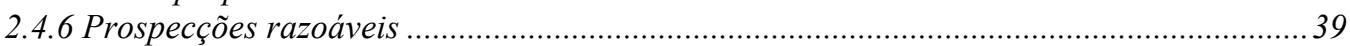

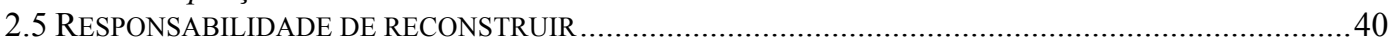

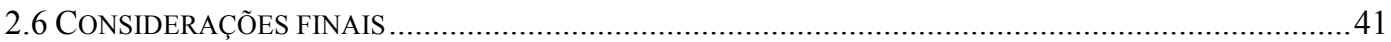

3 RESPONSABILIDADE DE PROTEGER: RETÓRICA OU REALIDADE? ..............................42

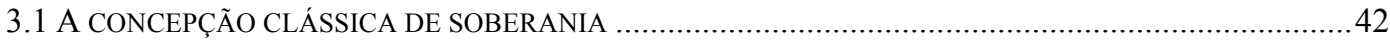

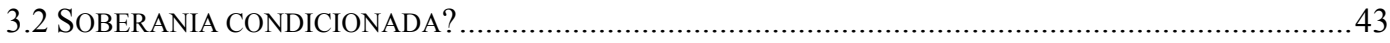

3.3 RESPONSABILIDADE DE PROTEGER E INTERVENÇÕES HUMANITÁRIAS: IMPLICAÇÕES ..................47

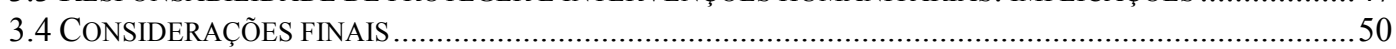

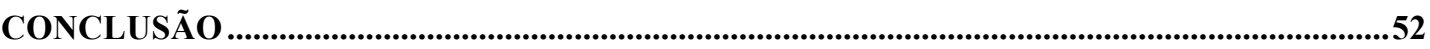

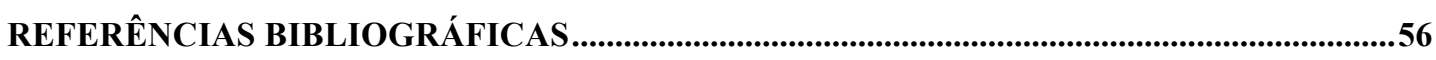

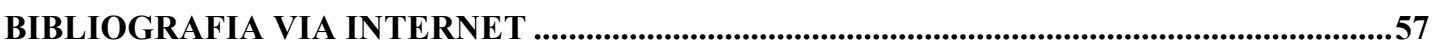




\section{INTRODUÇÃO}

Questão bastante controversa no âmbito do estudo das relações internacionais refere-se às intervenções humanitárias. Tal controvérsia deve-se ao fato de que quando se fala em intervenções para fins humanitários coloca-se em confronto dois conceitos caros às relações internacionais, quais sejam, soberania e proteção aos direitos humanos. Tais conceitos, embora não sejam opostos ou excludentes, freqüentemente se apresentam como concorrentes ou cuja convivência é muito problemática.

No início da década de 90, as teses a respeito da possibilidade de se utilizar a força armada em intervenções para deter graves violações de direitos humanos passaram a ser levantadas com maior freqüência. Essa intensificação do debate acerca do tema deu-se em um contexto histórico propício, marcado pelo fim da Guerra Fria e pela conseqüente modificação da ordem internacional. O fim das tensões Leste-Oeste baseadas em diferenças ideológicas possibilitou que temas como direitos humanos, anteriormente difíceis de serem discutidos mais amplamente, pudessem passar a dispor de espaço privilegiado na agenda internacional. Como desdobramento inevitável, a crescente preocupação com a proteção dos direitos humanos levou ao debate acerca de teses de que violações graves poderiam justificar a intervenção humanitária por parte da comunidade internacional.

Apesar de tudo, até o momento não há, no direito internacional, previsão normativa expressa permitindo o uso da força em tais situações. Dessa forma, a controvérsia principal que envolve o tema da intervenção humanitária reside, em última análise, no velho confronto no cenário político entre moralidade e legalidade. Essa é uma questão antiga e que, por si só, justificaria um alentado trabalho. Os objetivos de uma monografia, contudo, são 
bem mais limitados e, assim, decidiu-se examinar um caso ou, mais exatamente, como a questão vem sendo tratada no âmbito da Organização das Nações Unidas que, em larga medida, seria a instância onde um possível regime internacional para a questão pode vir a surgir efetivamente.

O relatório Responsabilidade de Proteger, elaborado pela Comissão Internacional sobre Intervenção e Soberania Estatal, foi produzido com a finalidade de fornecer contornos básicos para se tratar a questão das intervenções humanitárias. Para tanto, o relatório apresenta justificativas para o empreendimento de intervenções militares com propósitos humanitários e busca traçar alguns parâmetros acerca da forma como as intervenções devem ser levadas a efeito e quem teria legitimidade para intervir. Assim, o presente trabalho tem por finalidade examinar os pontos levantados pela Comissão a fim de responder às seguintes perguntas: o que diz o relatório Responsabilidade de Proteger? Quais são as contribuições que o documento traz para as teses a favor das intervenções humanitárias? Quais são as implicações que desses novos contornos?

A fim de responder a essas perguntas, inicialmente, faz-se um breve levantamento histórico da base doutrinária que fundamenta a idéia de intervenção humanitária. Procura-se fazer, no primeiro capítulo, uma incursão no conceito de guerra justa, o qual é apontado como gênese das atuais teses a favor das intervenções humanitárias. Em seguida, delineia-se a emergência do positivismo jurídico no direito internacional e a crescente preocupação com a proibição da guerra como meio legítimo de solução de controvérsias. Por fim, são apresentadas as principais teses contemporâneas que sustentam a idéia de que a comunidade internacional tem o direito, e até mesmo o dever, de realizar intervenções humanitárias. 
Após a apresentação desse levantamento, o segundo capítulo, de caráter descritivo, é dedicado à apresentação do relatório Responsabilidade de Proteger. Procura-se apresentar, nessa segunda parte do trabalho, os principais pontos levantados pela Comissão que o elaborou. Assim, são reproduzidos os argumentos expostos no documento, que justificariam as intervenções com propósitos humanitários, bem como as propostas de como esses empreendimentos devem ocorrer. Questões acerca de quem teria legitimidade para autorizar tais intervenções ou quando uma intervenção poderia ser colocada em prática são alguns dos pontos levantados como passíveis de discussão.

Por fim, no terceiro capítulo, busca-se examinar de forma crítica os argumentos apresentados pela Comissão e suas implicações. Dessa forma, procura-se apontar quais contribuições do relatório poderiam ser consideradas relevantes para o avanço da doutrina das intervenções humanitárias e quais seriam os pontos passíveis de controvérsias. Nesse sentido, analisa-se a proposta de adoção do conceito de soberania como responsabilidade apresentada pelo documento e suas implicações práticas. Traz-se à discussão algumas críticas elaboradas por estudiosos do tema e, a partir dessa análise, procura-se, enfim, extrair algumas conclusões que poderiam orientar possíveis respostas às perguntas inicialmente levantadas. 


\section{DAS INTERVENÇÕES HUMANITÁRIAS}

O conceito de intervenção humanitária pode variar dependendo do autor consultado, alguns apresentam uma conceituação mais abrangente enquanto outros sugerem entendimentos mais restritos. J. L. Holzgrefe propõe que a intervenção humanitária seja entendida como a ameaça ou o uso efetivo da força através das fronteiras de um Estado com a finalidade de prevenir ou cessar graves violações de direitos humanos sem a permissão do Estado que está sofrendo a intervenção ${ }^{1}$. Considerando que o presente trabalho tem por objetivo básico analisar o relatório Responsabilidade de Proteger, faz-se necessário tomar como ponto de partida o conceito apresentado pelo próprio documento. Nesse sentido, no Relatório a intervenção humanitária é entendida como "ação empreendida contra um Estado ou seus lideres, sem o seu consentimento, com propósitos entendidos como humanitários ou protetores". ${ }^{2}$ Ao referir-se à intervenção simplesmente como "ação empreendida", a definição inclui no conceito apresentado pelo Relatório, outras medidas coercitivas que não são apenas o emprego da força militar. Desse modo, pode-se dizer que o referido documento apresenta um entendimento mais abrangente do conceito de intervenção humanitária.

Contudo, ainda que se adote o entendimento do Relatório, deve-se ressaltar que uma maior atenção será dada às intervenções que envolvem o uso da força porquanto essas são as que causam maiores controvérsias. Assim, no presente capítulo, pretende-se fazer

\footnotetext{
${ }^{1}$ HOLZGREFE, J. L. “The Humanitarian intervention debate”. In: HOLZGREFE, J. L.; KEOHANE, Robert O. (org.). Humanitarian Intervention: ethical, legal and political dilemmas. 5 ed. Cambridge: Cambridge University Press, 2007, p. 18.

2 ICISS. The Responsibility to Protect: Report of the International Commission on Intervention and State Sovereignty. Toronto. IDRC, 2002, p. 8.

Tradução livre, no original: "action taken against a state or its leaders, without its or their consent, for purposes which are claimed to be humanitarian or protective."
} 
um breve levantamento histórico da doutrina subjacentes às intervenções humanitárias. Inicialmente, procurar-se-á trazer à discussão a teoria da guerra justa, que pode ser entendida como a gênese das teorias atuais das intervenções humanitárias. Em um segundo momento, seguindo uma ordem cronológica, far-se-á uma incursão no crescimento do positivismo jurídico no direito internacional e na evolução das regras proibitivas ao uso da força. Por fim, serão apresentados os principais fundamentos contemporâneos que sustentam a teoria da intervenção humanitária.

\subsection{A doutrina da guerra justa}

A doutrina da intervenção humanitária tem sua origem na teoria da guerra justa, formulada já na Grécia e Roma antigas e, posteriormente, desenvolvida pelos escolásticos, jus naturalistas e na tradição do Direito Positivo. Nesses escritos já se percebe o conflito entre o ímpeto moral da guerra contra as diferenças religiosas e as restrições legais que foram instituídas sobretudo a partir da Paz de Westfália. ${ }^{3}$

Uma das principais contribuições veio dos escolásticos que trouxeram para cristandade os argumentos para a formulação de uma teoria da guerra justa compatível com a moral e a doutrina da Igreja. Escrevendo no século XIII, Tomás de Aquino argumentava que para que uma guerra fosse considerada justa era necessário que fossem preenchidos três requisitos. O primeiro deles consubstanciava-se na autoridade soberana daquele em nome de quem a guerra seria empreendida. Esse primeiro elemento apresentado por Tomás de Aquino

\footnotetext{
${ }^{3}$ CHESTERMAN, Simon. Just war or Just peace? Humanitarian intervention and international Law. Nova York: Oxford University Press, 2001, p. 7.
} 
referia-se à proibição da guerra empreendida por agentes privados, os quais, deveriam submeter suas contendas ao tribunal de seu superior. ${ }^{4}$

O segundo requisito seria a justa causa. Tal requisito está ligado à idéia de guerra como punição ou busca de reparação. Um Estado somente poderia ser atacado quando tivesse cometido alguma injúria ou falta que prejudicasse notoriamente outro Estado. Por último, Tomás de Aquino argumentava que a motivação para a guerra deveria ser legítima, uma vez que a guerra apenas poderia ser utilizada para promover o bem ou evitar o mal..$^{5} \mathrm{~A}$ noção de justa causa para a guerra apresentada por Aquino estava ligada à noção de justo dentro da concepção do cristianismo. Na verdade, seria justa a guerra desde que fundamentada nos preceitos do cristianismo.

Posteriormente, a teoria da guerra justa de Tomás de Aquino foi retrabalhada por Francisco de Vitória (1480-1546) e por Francisco Suarez (1548-1617). Argumentavam que a guerra poderia ser considerada justa se, além de satisfazer os requisitos de Tomas de Aquino, fosse realizada de forma proporcional. Suarez argumentava que a justa causa deveria ser grave o suficiente para ensejar uma reação armada. ${ }^{6}$

Outro pensador que contribuiu para formação da atual doutrina da intervenção humanitária foi o jurista holandês Hugo Grotius. De acordo com Chesterman, Grotius trouxe dois argumentos importantes: a legitimidade da guerra como punição, e a

${ }^{4}$ Apud BROWNLIE, Ian. International law and the use of force by States. Nova York: Oxford University Press, 1963, p. 6.

${ }^{5}$ Apud Ibidem, p. 6.

No original:

"In order for a war to be just three things are necessary. First the authority of the sovereign by whose command the war is to be waged. For it is not the business of the private individual to declare was, for the can seek for redress of his rights from the tribunal of his superior...

Secondly, a just cause is required, namely that those who are attacked should be attacked because they deserve it on account of some fault.

Thirdly, it is necessary that the belligerents should have a rightful intention, so that they intend the advancement of good, or the avoidance of evil."

${ }^{6}$ AREND, Anthony Clark; BECK, Robert J. International law and the use of force. New York: Routledge, 1993, p. 14. 
legitimidade da guerra empreendida em nome de outros. ${ }^{7}$ Porém, a grande contribuição que Grotius traz para a teoria da guerra justa é a secularização da moral. Diferentemente, dos escolásticos, que defendiam uma moral baseada nos ensinamentos do Cristianismo, Grotius entendia que seria moralmente justa a guerra empreendida com base no direito natural de cada indivíduo ${ }^{8}$.

Escrevendo em um período marcado pelas guerras religiosas, o jurista holandês defende a ilegitimidade da guerra motivada pelas diferenças de interpretação de preceitos do Cristianismo ou da guerra empreendida contra aqueles que se recusavam a aceitá-los. Grotius defende a necessidade da guerra como punição porquanto entendia que cada indivíduo possuía direitos naturais, ou seja, decorrentes de sua condição humana, e que a sociedade internacional carecia de uma entidade internacional que pudesse garantir o exercício desses direitos. ${ }^{9}$ Dessa forma, a guerra como punição poderia ser empreendida contra aqueles que violassem o direito dos soberanos, mas também poderia ser empreendida contra os soberanos que "excessivamente violassem o direito natural ou o direito das nações em relação a qualquer indivíduo"10.

Segundo Chesterman, a grande contribuição de Grotius, portanto, foi apresentar uma fundamentação secular para a guerra justa. ${ }^{11}$ Ao contrário dos escolásticos, Grotius argumentou não ser justa a guerra feita por motivos religiosos, mas apenas as guerras empreendidas para defender direitos naturais. Essa inovação intelectual trazida por Grotius acabou sendo ainda mais valorizada por ocasião da Paz de Westfália ${ }^{12}$, que proscreveu as

\footnotetext{
${ }^{7}$ CHESTERMAN, Simon. Just war or Just peace? Humanitarian intertervention and international Law. Nova York: Oxford University Press, 2001, p. 10.

${ }^{8}$ Ibidem, p. 10-11.

${ }^{9}$ GROTIUS, Hugo. O Direito da guerra e da paz. Vol. II. Porto Alegre: UNIJUI, 2004, p. 979.

${ }^{10}$ Ibidem, p. 979.

${ }^{11}$ CHESTERMAN, Simon. Op. cit, p. 13.

${ }^{12}$ CHESTERMAN, Simon. Op. cit, p. 13.
} 
guerras religiosas e estabeleceu o princípio cujus rejus, ejus religio, ou seja, cada soberano seria livre para determinar a religião de seus súditos.

A importância conferida ao direito natural por Grotius também serviu de fundamento para a consideração de que seriam justas as guerras realizadas em nome dos oprimidos. Para o jurista holandês, seria legítimo recorrer ao uso da força nas situações em que súditos de um outro soberano estivessem sofrendo opressão. Argumenta o autor que nos casos em que um tirano estivesse abusando de seus súditos, a sociedade poderia atuar de modo a impedir tais violações. ${ }^{13}$ Grotius não defendia, no entanto, um dever de intervir, mas sim um direito que poderia ou não ser exercido, dependendo da conveniência para o interventor $^{14}$.

Ainda que as idéias jusnaturalistas de Grotius tenham, de certa forma, influenciado a posição adotada nos tratados de Westfália com relação às guerras religiosas, um posicionamento mais voltado para o não-intervencionismo passou a ser reconhecido de forma crescente pela sociedade internacional a partir, sobretudo, de 1648. De acordo com Chesterman, essa tendência pode ser observada em três áreas: "no crescimento do positivismo jurídico no direito internacional; em um comprometimento mais abrangente com relação à soberania e à liberdade moral de cada Estado; e com relação às mudanças políticas ocorridas durantes os séculos XVIII e XIX,"15.

A Paz de Westfália introduziu um conceito de extrema importância para as relações internacionais, qual seja, a soberania dos Estados. De forma simplificada, o

\footnotetext{
${ }^{13}$ CHESTERMAN, Simon. Just war or Just peace? Humanitarian intertervention and international Law. Nova York: Oxford University Press, 2001, p. 15.

${ }^{14}$ Ibidem, p. 14.

${ }^{15}$ Ibidem, p. 16.

Tradução livre, no original:

"This can be seen in three areas: the rise of positivism in international law; a more general commitment to sovereignty and to the state as a morally free entity; and in the changing political climate of the eighteenth and nineteenth centuries".
} 
reconhecimento da soberania significava que: os monarcas deteriam o poder absoluto sobre seus territórios, de onde decorre o princípio da não-interferência; os Estados passaram a ser considerados juridicamente iguais no âmbito internacional; e os Estados não se sujeitariam a nenhuma ordem superior internacional, a não ser quando consentissem. A nova ordem que se instalava era agora horizontal.

Portanto, a fase jusnaturalista do direito internacional começava a fenecer, mormente, a partir da segunda metade do século XIX, momento em que o positivismo jurídico passa a ganhar espaço no direito internacional. Esse novo período é caracterizado pela importância ainda maior do reconhecimento da soberania dos Estados, pela separação entre direito internacional e direito interno e pelo direito irrestrito de o Estado recorrer à guerra para solucionar controvérsias. ${ }^{16}$

De acordo com Ian Brownlie, os escritores clássicos do direito internacional do período acreditavam existir um direito de intervenção humanitária. ${ }^{17} \mathrm{O}$ recurso à guerra poderia ser utilizado para punir injúrias e injustiças. Porém, ainda que os juristas da época entendessem ser possível falar-se em guerra justa, havia distinções quanto às justificavas para uma guerra. Alguns entendiam ser "guerra justa" aquela empreendida para libertar uma nação que estivesse sendo oprimida por outra. Outros consideravam que apenas as guerras realizadas para deter matanças generalizadas poderiam ser entendidas como justas. Havia também os que defendiam ser justa a guerra contra a tirania, contra a prática de violações

\footnotetext{
${ }^{16}$ GREWE, Wilhelm G. The epochs of international law. Berlin; Nova York: De Gruyter, 2000, p. 512.

${ }^{17}$ BROWNLIE, Ian. International law and the use of force by States. Nova York: Oxford University Press, 1963, p. 338.
} 
cruéis ou contra a perseguição religiosa. Por último, havia os doutrinadores que defendiam a utilização da guerra justa para pôr fimm a governos falidos ou que rumavam para a anarquia. ${ }^{18}$

Brownlie, por sua vez adotando uma postura crítica, argumenta que o entendimento no sentido da possibilidade de se recorrer à guerra nas situações antes mencionadas trazia como conseqüência o fato de que a doutrina da guerra justa "estava aberta a abusos uma vez que apenas Estados poderosos poderiam lançar mão de medidas desse tipo." ${ }^{19}$ Em outras palavras, na prática, ao se adotar uma tal doutrina apenas os Estados com maior poderio militar poderiam propor-se a tais medidas. De acordo com Brownlie:

quando as operações militares eram justificadas como "intervenção humanitária", essa era apenas uma das diversas caracterizações declinadas e as circunstâncias freqüentemente indicavam a presença de motivos egoístas. ${ }^{20}$

Por ser o período em questão marcado pela admissibilidade da guerra empreendida pelo soberano na busca de seus interesses, torna-se difícil o estabelecimento de quais guerras eram de fato justas e quais eram comuns e decorrentes apenas de interesses variados. Uma vez que a guerra era medida de solução de controvérsias legítimas, os motivos para uma ação armada poderiam ser baseados tanto no interesse nacional como na justa causa.

\subsection{O Direito Internacional e o uso da força}

Como já mencionado anteriormente, até o início do século XIX a guerra constituía meio legítimo de solução de litígios no âmbito internacional. Como afirma Quoc Dinh Nguyen et al "até 1919, não podemos ver a guerra senão como uma manifestação

\footnotetext{
${ }^{18}$ BROWNLIE, Ian. International law and the use of force by States. Nova York: Oxford University Press, 1963 , p. 338.

${ }^{19}$ Ibidem, p. 338.

${ }^{20}$ Ibidem, p. 338-339.

Tradução livre, no original: “when military operations were justified as 'humanitarian intervention', this was only one of several characterizations offered and circumstances frequntly indicated the presence of selfish motives".
} 
normal da soberania dos Estados". ${ }^{21}$ Foi apenas a partir de então que tratados foram celebrados com o intuito de limitar a utilização da força como forma de resolução de conflito. Essa preocupação ganhou força ao longo do século XX, período no qual o mundo assistiu ao crescente avanço tecnológico associado ao poderio militar e ao aumento do potencial de destruição dos novos equipamentos bélicos. ${ }^{22}$

Uma análise dos tratados que versam sobre a matéria revela que a instituição de barreiras ao uso da força deu-se de forma gradual. Mesmo após a Primeira Guerra Mundial, “os Estados não estavam preparados para aceitar uma solução tão drástica. O Pacto da Sociedade das Nações trouxe em seu preâmbulo o compromisso, assumido pelos Estados contratantes, de aceitar certas obrigações de não recorrer à guerra." ${ }^{23}$ Mais adiante, o Pacto estabeleceu situações nas quais o uso da força seria lícito e outras em que o recurso às armas seria proibido. Seria ilegal a guerra de agressão e conquista, conforme dispõe o artigo $10^{\circ}$ do Pacto, ao passo que seria lícito recorrer ao uso da força nas situações previstas nesse documento normativo.

Alguns anos depois da instituição da Liga das Nações, um novo tratado foi celebrado com o fim de limitar o recurso à guerra, o Pacto Briand-Kellogg. O referido Pacto, é apontado por alguns juristas como tendo sido um passo decisivo para a proscrição da guerra. ${ }^{24} \mathrm{O}$ documento surgiu a partir de negociações bilaterais entre os Estados Unidos da

\footnotetext{
${ }^{21}$ NGUYEN, Quoc Dinh; DAILLIER, Patrick e PELLET, Alain. Direito Internacional Público. 2 ed. Lisboa: Fundação Calouste Gulbekian, 2003, p. 953.

${ }^{22}$ Ibidem, p. 954.

${ }^{23}$ PACTO DA SOCIEDADE DAS NAÇÕES. Preâmbulo:

"As Altas Partes Contratantes

Considerando que, para desenvolver a cooperação entre as Nações e para lhes garantir a paz e a segurança, importa:

aceitar certas obrigações de não recorrer à guerra;"

${ }^{24}$ NGUYEN, Quoc Dinh; Op. cit, p. 954.

Nesse sentido também argumenta Francisco Rezek. O Pacto "representaria um nítido progresso em relação ao documento-base da SDN. A guerra, aqui, já não é alternativa a ser evitada. Os Estados pactuantes condenamna, e a ela renunciam [...]”. REZEK, Francisco. Direito internacional público. 11 ed. São Paulo: Saraiva, 2003, p. 373.
} 
América e a França, que pretendiam assumir um compromisso renunciando a todo recurso à guerra nas suas relações bilaterais. Posteriormente, os negociadores entenderam por bem abrir o Tratado à adesão de outros Estados. Dessa forma, o Pacto acabou sendo inicialmente subscrito por 15 Estados e ficou aberto a adesões. ${ }^{25}$ Em 1939, já possuía 63 Estados-parte. O Pacto colocava termo à regra tradicional da competência discricionária da guerra. ${ }^{26}$

No entanto, o fracasso do Pacto Kellogg-Briand, e da própria Liga das Nações, ficou por demais evidente diante da eclosão da Segunda Guerra Mundial. Bem mais destruidora do que a Primeira, a Segunda Grande Guerra revelou a necessidade de regras mais rígidas e claras referentes à proibição do uso da força. Essa preocupação mostrou-se presente por ocasião da celebração da Carta das Nações Unidas em 1945. De acordo com alguns juristas, do ponto de vista normativo, a evolução da proibição do uso da força estaria completa com a Carta da $\mathrm{ONU}$, uma vez que tal documento proíbe todo o recurso à força. ${ }^{27}$ Nesse documento a guerra passa a ser um recurso excepcional, permitida apenas em hipóteses bastante restritas.

O artigo 2.4 da Carta das Nações Unidas prevê que os Estados pactuantes abster-se-ão de recorrer às armas para a solução de conflitos. ${ }^{28}$ Duas são as exceções à regra geral de proscrição à guerra trazidas pela Carta. A primeira hipótese diz respeito à legítima defesa, a qual pode ser individual ou coletiva. A Carta também admite o recurso à força

\footnotetext{
${ }^{25}$ NGUYEN, Quoc Dinh; DAILLIER, Patrick e PELLET, Alain. Direito Internacional Público. 2 ed. Lisboa: Fundação Calouste Gulbekian, 2003, p. 954-956.

${ }^{26}$ Ibidem, p. 956.

${ }^{27}$ Ibidem, p. 956.

${ }^{28}$ Carta da Organização das Nações Unidas

ARTIGO 2 - A Organização e seus Membros, para a realização dos propósitos mencionados no Artigo 1, agirão de acordo com os seguintes Princípios:

4. Todos os Membros deverão evitar em suas relações internacionais a ameaça ou o uso da força contra a integridade territorial ou a dependência política de qualquer Estado, ou qualquer outra ação incompatível com os Propósitos das Nações Unidas.
} 
quando o Conselho de Segurança das Nações Unidas entender por necessário a implementação de tal recurso para a manutenção da paz e da segurança internacionais.

No que se refere à legítima defesa, a Carta estabelece que o Estado que sofrer agressão poderá recorrer ao uso da força, mas muito se discutiu acerca do que poderia ser classificado como agressão. Diante dessas discussões, a Assembléia Geral das Nações Unidas adotou a resolução 3.314 de 14 de dezembro de 1974, afirmando entender por ato de agressão "o emprego da força armada por um Estado contra a soberania, a integridade territorial ou a independência política de um outro Estado, ou de qualquer outra forma incompativel com a Carta das Nações Unidas". ${ }^{29}$ Quanto ao uso da força por determinação do Conselho de Segurança, a Carta admite essa possibilidade sempre que o Conselho entender que um determinado conflito ameaça a paz e a segurança internacionais, porém, deve o próprio Conselho demonstrar que as soluções pacíficas de controvérsias são precárias para resolução do conflito.

Dessa forma, da analise desses documentos normativos internacionais, percebe-se que, a partir do início do século XX, passou a haver uma maior preocupação, por parte dos Estados, de criar obstáculos para a utilização da guerra como meio de solução de controvérsias. Contudo, já no último quartel do século passado começaram a surgir novas interpretações das regras proibitivas ao uso da força e algumas dessas interpretações referemse à questão das intervenções humanitárias.

\subsection{O doutrina contemporânea das intervenções humanitárias}

Diante da proibição da guerra, reafirmada pela Carta das Nações Unidas, a discussão acerca das intervenções humanitárias ganhou novo contorno. Como apontam Alex

\footnotetext{
${ }^{29}$ ASSEMBLÉIA GERAL DAS NAÇÕES UNIDAS. Resolução 3314 (XXIX) de 14 de dezembro de 1974. Disponível em: http://untreaty.un.org/cod/avl/ha/da/da.html. Acessado em: 23.01.2009.
} 
Bellamy e Nicholas Wheeler, os argumentos utilizados para a defesa das intervenções humanitárias podem ser divididos, quanto aos fundamentos que os sustentam, em dois grupos: os normativos e os morais. ${ }^{30}$

\title{
1.3.1 Fundamentos normativos à intervenção humanitária
}

As teses a favor das intervenções humanitárias que possuem fundamento normativo podem pautar-se em interpretações da Carta das Nações Unidas ou no reconhecimento da existência de normas consuetudinárias internacionais que permitiriam a realização de intervenções com propósitos humanitários. Nada impede, no entanto, que se defenda a legitimidade das intervenções com base nesses dois tipos de fundamento normativo.

\subsubsection{Interpretações do artigo 2.4 da Carta das Nações Unidas}

Uma primeira linha de pensamento que procura justificar a legitimidade das intervenções humanitárias tem por base artigo 2.4 da Carta da ONU, que assim é enunciado:

\begin{abstract}
"Os membros deverão abster-se nas suas relações internacionais de recorrer à ameaça ou ao uso da força, quer seja contra a integridade territorial ou a independência política de um Estado, quer seja de qualquer outro modo incompatível com os objetivos das Nações Unidas."
\end{abstract}

As intervenções humanitárias fundamentadas nesse dispositivo desenvolvem duas linhas de interpretação. A primeira delas diz respeito à parte que proíbe a ameaça ou o uso da força, propriamente dito, contra a integridade territorial dos Estados e à independência política desses. Essa corrente de interpretação defende que a proibição mencionada no artigo 2.4 da Carta das Nações Unidas proíbe apenas, e tão-somente, a intervenção que tenha por objetivo violar a integridade territorial ou a independência política

\footnotetext{
${ }^{30}$ BELLAMY, Alex J. e WHEELER, Nicholas. "Humanitarian intervention in world politics". In: BAYLIS, J. e SMITH, S (org.). The Globalization of world politics: An Introduction to international relations. Nova York: Oxford Univesity Press, 2005, p. 557.
} 
de um Estado. ${ }^{31}$ Fernando Tesón, jurista identificado com essa corrente, entende ser essa interpretação restritiva a mais correta porquanto os elaboradores da Carta poderiam ter tornado a disposição mais ampla se assim o quisessem. Bastaria, para tanto, argumenta Tesón, extrair do dispositivo a expressão "quer seja contra a integridade territorial ou a independência politica de um Estado". 32

Decorre dessa interpretação, portanto, que não haveria, na Carta das Nações Unidas, proibição às intervenções humanitárias. Considerando que o referido documento normativo proíbe a ameaça ou o uso da força apenas nas hipóteses em que atentarem contra a integridade territorial de um Estado ou contra sua liberdade política, as intervenções humanitárias não seriam proibidas, uma vez que tais medidas não teriam a intenção de conquistar territórios ou subjugar politicamente o Estado, mas apenas evitar que graves violações de direitos humanos ocorram. ${ }^{33}$

Apesar de tudo, ao analisar os Travaux Préparatoires para a Carta da ONU, Chesterman verifica que chegou a haver, durante os trabalhos preparatórios, significativa preocupação no sentido de que o dispositivo fosse interpretado de forma restrita e se registrou que a intenção dos pactuantes era a de que o uso da força fosse proibido de maneira ampla. ${ }^{34}$ O texto inicial proposto possuía a seguinte redação: “Todos os membros da Organização deverão abster-se, em suas relações internacionais, da ameaça ou do uso da força em qualquer ação incompativel com os propósitos da Organização." ${ }^{, 35}$ A delegação australiana,

\footnotetext{
${ }^{31}$ CHESTERMAN, Simon. Just war or Just peace? Humanitarian intervention and international Law. Nova York: Oxford University Press, 2001, p. 48.

${ }^{32}$ Ibidem, p. 51.

${ }^{33}$ Ibidem, 2001, p. 51.

${ }^{34}$ Ibidem, 2001, p. 51.

35 The Dumbarton Oaks Proposals. Disponível em: http://www.ibiblio.org/pha/policy/1944/441007a.html. Acessado em: 26/02/2009.

Tradução livre, no original:

CHAPTER II. PRINCIPLES
} 
por sua vez, propôs a inclusão da expressão “quer seja contra a integridade territorial, ou a independência política de um Estado". A despeito das manifestações das delegações do Brasil e da Noruega, referentes à possível ambigüidade de tal redação, o texto final acabou por adotar a proposta australiana. ${ }^{36}$ Porém, a intenção não era restringir a proibição do uso da força, mas reforçar a vedação de se recorrer à guerra contra a integridade territorial e a liberdade política de um Estado. ${ }^{37}$ Destarte, conclui Brownlie no mesmo sentido de Chesterman:

“A conclusão a que se chegou por meio dos travaux préparatoires é a de que a frase em discussão não foi pretendida para ser restritiva mas, ao contrário, para prover mais garantias específicas a pequenos Estados e não pode ser interpretada como tendo um efeito qualificador" 38

A argumentação segundo a qual a utilização da força com outra finalidade que não a conquista territorial ou a subjugação política seria compatível com o texto da Carta da ONU foi objeto de acalorados debates perante a Corte Internacional de Justiça no caso do Canal de Corfu, no qual litigavam Albânia e Reino Unido. Naquela ocasião, o Reino Unido alegou que a operação de retirada de minas não representava ameaça à integridade territorial da Albânia e tampouco à independência política do país, mas o argumento não prosperou e foi rejeitado pela Corte. Entendeu a CIJ que operação violou a soberania do Estado albanês, negando assim a tese suscitada pelo Reino Unido. ${ }^{39}$

4.All members of the Organization shall refrain in their international relations from the threat or use of force in any manner inconsistent with the purposes of the Organization.

${ }^{36}$ BROWNLIE, Ian. International law and the use of force by States. Nova York: Oxford University Press, 1963, p. 266-267.

${ }^{37}$ Ibidem, p. 266.

${ }^{38}$ Ibidem, p. 267.

Tradução livre, no original:

The conclusion warranted by the travaux préparatoires is that the phrase under discussion was not intended to restrictive but, on the contrary, to give more specific guarantees to small states and taht it cannot be interpreted as having a qualifying effect.

${ }^{39}$ CHESTERMAN, Simon. Just war or just peace? humanitarian intervention and international law. Nova York: Oxford University Press, 2001, p. 50. 
A segunda tese acerca da possibilidade das intervenções relacionadas ao artigo 2.4 da Carta, refere-se ao trecho do dispositivo que diz: "quer seja de qualquer outro modo incompativel com os objetivos das Nações Unidas". De acordo com esse entendimento seria possível a ameaça ou uso da força, desde que a justificativa estivesse de acordo com os propósitos da Carta da ONU. Tesón utiliza-se desse argumento para justificar um direito de intervenção humanitária. Argumenta esse autor que, uma vez que as intervenções de caráter humanitário estariam de acordo com os propósitos da Carta das Nações Unidas, poder-se-ia falar na possibilidade de uso da força com o objetivo de proteger direitos humanos. No entanto, essa interpretação tornaria, da mesma forma que a primeira, a proibição do artigo 2.4 restrita às ações que estivessem em desacordo com os objetivos da Carta. Tal entendimento é incongruente com o objetivo precípuo da Organização, qual seja, a manutenção da paz e da segurança internacionais. Seria, portanto, incoerente admitir que a proibição à ameaça ou uso da força trazida pela Carta seja adstrita a situações nas quais o motivo fosse contrário aos objetivos da Organização. Mais coerente parece ser o argumento segundo o qual o trecho “ou de qualquer outra forma incompativel com os objetivos da Organização" é entendido como uma forma de se reforçar a proibição do uso da força nessas ocasiões. ${ }^{40}$

\subsubsection{Intervenção humanitária como direito internacional consuetudinário}

\footnotetext{
${ }^{40}$ Nesse sentido argumenta Chesterman: "As matter of construction it seems clear that the provision does not limit the prohibition of the use of force to instances where its application is inconsistent with the Organization's purposes. On the contrary, the use of the words 'or in any other' suggests an inclusive meaning: that the use of force against territorial integrity or political independence of a state is inconsistent with the purposes of the United Nations. The better reading, then, is hat any threat or use of force is not directed against the territorial integrity or political independence of a state but is inconsistent with Article I of the Charter is also illegal. In: CHESTERMAN, Simon. Just war or just pece? humanitarian intervention and international law. New York: Oxford University Press, 2001, p.52. Nesse mesmo sentido argumenta Brownlie: "The phrase was not intended by the draftsmen to have a restrictive effect on paragraph 4 or on Article 51, and indeed it was probably meant to reinforce the prohibition of paragraph 4 and, perhaps, to refer to the legality of force when this took the form of enforcement action sanctioned by the Security Council'. In: BROWNLIE, Ian. International law and the use of force by states. New York, Oxford University Press, 1963, p. 268.
} 
Além dos argumentos já apresentados, existe um outro que defende a intervenções humanitárias. O entendimento favorável a intervenção internacional em questõs humanitárias desenvolve-se de forma associada à Carta das Nações Unidas. Essa corrente argumenta que existe um direito consuetudinário internacional que contempla de forma inequívoca a implementação de intervenções humanitárias. ${ }^{41}$ Essa argumentação, no entanto, foi rebatida pela Corte Internacional de Justiça no curso do julgamento do caso Nicarágua contra Estados Unidos da América sobre ações militares e para-militares em território da Nicarágua. Nesse caso, ao analisar os elementos constitutivos do direito consuetudinário, concluiu a Corte que não se pode atestar a existência de um direito consuetudinário de intervenção humanitária:

A Corte conclui que os atos que constituem uma violação ao princípio costumeiro de não-intervenção também constituirão, caso tais princípios envolvam o uso da força, uma violação ao princípio do não uso da força nas relações internacionais. ${ }^{42}$

$\mathrm{Na}$ apreciação do mérito, a Corte afirmou que para a formação de um direito consuetudinário no âmbito internacional seria necessária a presença de dois requisitos, quais sejam, prática reiterada e opinio juris sive necessitatis. ${ }^{43}$ De outra forma, concluiu a Corte que, para que seja considerado direito consuetudinário internacional, deve o ato ser praticado de forma reiterada e deve haver um entendimento, ainda que tácito, de que aquela prática constitui um costume internacional. Na verdade, tais elementos já haviam sido elencados pela Corte por ocasião do julgamento do caso North Sea Continental Shelf.

\footnotetext{
${ }^{41}$ CHESTERMAN, Simon. Just war or just peace? humanitarian intervention and international law. Nova York: Oxford University Press, 2001, p. 53.

42 CORTE INTERNACIONAL DE JUSTIÇA - Caso Nicarágua v. Estados Unidos da América. Méritos. 27 de junho de 1986, pp. 99-100, par. 209.

Tradução livre, no original:

The Court therefore finds that no such general right of intervention, in support of an opposition within another State, exists in contemporary international law. The Court concludes that acts constituting a breach of the customary principle of non-intervention will also, if they directly or indirectly involve the use of force, constitute a breach of the principle of non-use of force in international relations.

${ }^{43}$ CORTE INTERNACIONAL DE JUSTIÇA - Caso Nicarágua v. Estados Unidos da América. Méritos. 27 de junho de 1986, pp. 98-99, par. 207.
} 
Dessa forma, a ameaça ou o uso da força para fins humanitários deveria constituir uma prática reiterada internacionalmente e aceita pelos Estados como sendo direito para que pudesse ser considerada norma de direito internacional consuetudinário. Ao analisar as intervenções realizadas a partir da Carta das Nações Unidas, Chesterman chega à conclusão de que tal prática reiterada não existe. ${ }^{44} \mathrm{O}$ que se verifica, de fato, é que as intervenções foram realizadas por motivos diversos e que, portanto, não se pode reconhecê-las como parte de um costume aceito internacionalmente.

\subsubsection{Fundamentos morais à intervenção humanitária}

Além dos argumentos de caráter normativo, há ainda, teses que sustentam a legitimidade da intervenção humanitária fundada em princípios morais. Como aponta Chesterman, essa teoria seria equivalente a uma remodelação daquilo que Grotius havia apresentado como guerra em nome dos oprimidos. ${ }^{45}$ Os defensores dessa corrente partem do pressuposto de que a Organização das Nações Unidas possui como princípio basilar a proteção dos direitos humanos. Tal princípio estaria em igualdade de importância com o objetivo de manter a paz e a segurança internacionais. Nesse sentido, considerando que a violação aos direitos humanos poderia constituir ameaça à paz e à segurança internacionais, poder-se-ia admitir o uso da força para proteger tais direitos. ${ }^{46}$

\footnotetext{
${ }^{44}$ Em Just war or just peace? Humanitarian intervention and international law, Simon Chesterman analisa os seguintes casos: 1. Intervenção belga no Congo (leopoldville) - 1960; 2. Intervenção belga e norte-americana no Congo (Operação Stanleyville) - 1964; 3. Intervenção norte-americana na República Dominicana - 1965; 4. Intervenção da Índia no Paquistão do Leste/Bangladesh - 1971; 5. Intervenção israelense em Uganda (Oeração Entebbe) - 1976; 6. Intervenção belga e francesa no Zaire - 1978; 7. Intervenção da Tanzânia em Uganda - 1978-9; 8. Intervenção do Vietnã em Campuchea (Cambodia) - 1978-9; 9. Intervenção da França na República Central da África - 1979, 10. Intervenção norte-americana em Granada - 1983; 11. Intervenção norte-americana no Panamá - 1989-90; 12. Intervenções “coletivas” na Libéria, no Iraque, em Serra Leoa e no Kosovo.

${ }^{45}$ CHESTERMAN, Simon. Just war or just peace? humanitarian intervention and international law. Nova York: Oxford University Press, 2001, p. 37.

${ }^{46}$ AREND, Anthony Clark; BECK, Robert J. International law and the use of force. Nova York: Routledge, 1993, PP. 132-133.
} 


\subsection{Considerações finais}

No conjunto, o exame do quadro doutrinário da intervenção humanitária mostram que a noção implícita nesse instituto remonta à teoria da guerra justa, a qual com o passar do tempo passou a ser cada vez mais restrita seja em razão da evolução do quadro político e social, seja em função da crescente precariedade e vulnerabilidade da condição humana diante dos avanços tecnológicos que tornam cada vez mais inaceitável a perspectiva de uma guerra. Os tratados celebrados durante o século XX refletem a preocupação crescente dos Estados no sentido de limitarem a utilização do uso da força nas relações internacionais. Por outro lado, a partir do fim da guerra fria, percebe-se uma maior preocupação com a proteção dos direitos humanos. Tal tendência acabou por engendrar a formulação de teorias que conformassem as intervenções humanitárias às normas de direito internacional proibitivas do uso da força. 


\section{RESPONSABILIDADE DE PROTEGER}

$\mathrm{Na}$ esteira da movimentação intelectual em busca de sólidas fundamentações que justificassem intervenções humanitárias, a Assembléia-Geral das Nações Unidas adotou, em 2005, o relatório Responsabilidade de Proteger. Esse documento foi elaborado na tentativa de responder aos desafios, relacionados às intervenções humanitárias, que se apresentavam à comunidade internacional a partir do fim da Guerra Fria. Na verdade, a partir já do período imediatamente posterior à Segunda Guerra Mundial, relevantes modificações ocorreram no cenário internacional. Uma delas foi o surgimento de novos Estados, o que, conseqüentemente, trouxe um número maior de demandas baseadas em interesses distintos. Após a Guerra Fria essas demandas tornaram-se ainda mais evidentes. Novos conflitos surgiram, sobretudo no âmbito doméstico de alguns Estados mais pobres. Dada a inter-conectividade do mundo atual e face ao fluxo de informações essas crises tornaram-se desafios não apenas para os Estados onde se desenvolvem, mas também motivos de preocupação para toda a comunidade internacional. ${ }^{47}$

Com efeito, o preço político da omissão diante de crises humanitárias elevase na medida em que os meios de comunicação informam, de modo cada vez mais amplo, o que ocorre nos vários rincões do mundo. As imagens dramáticas dessas crises passam a ser televisionadas em tempo real, provocando a interesse e indignação concitando a necessidade de uma ação efetiva daqueles que estão no poder em toda parte. Apesar de tudo, as instâncias políticas internacionais não parecem possuir respostas aptas a enfrentar efetivamente esse tipo de desafio. Não há consenso acerca de quando se deve agir ou de quem seria a competência para tomar as iniciativas e autorizar uma possível intervenção.

\footnotetext{
${ }^{47}$ ICISS. Responsibility to Protect, p. 5.
} 
Diante do quadro de flagrante despreparo, da comunidade internacional, para lidar com a questão das crises humanitárias, o governo do Canadá propôs, na Assembléia Geral das Nações Unidas de setembro de 2000, a criação da Comissão Internacional sobre Intervenção e Soberania Estatal (ICISS). ${ }^{48}$ A Comissão tinha como mandato promover o debate acerca dos aspectos políticos, morais, operacionais e legais das intervenções humanitárias e, ao final, elaborar um parecer que pudesse fornecer os subsídios necessários à adoção de um entendimento político comum sobre o tema das intervenções humanitárias. ${ }^{49}$

\subsection{Responsabilidade de Proteger}

A questão central com a qual a Comissão pretendia trabalhar referia-se ao difícil dilema entre a prerrogativa da soberania dos Estados e o dever moral de proteger a vida e os direitos associados à condição humana. A fim de conciliar essas duas dimensões, a Comissão tomou como ponto de partida uma visão de soberania distinta daquela que entende a prerrogativa da soberania como algo absoluto. O entendimento manifesto foi o de que o fato de o direito internacional ter evoluído desde a formulação da Carta da ONU, criando novas obrigações internacionais para os Estados, trouxe consigo a necessidade de uma reinterpretação do conceito de soberania. Essa nova concepção implicaria o reconhecimento de que, internamente, soberania significaria a responsabilidade de "respeitar a dignidade e os direitos básicos de todo o povo dentro do Estado". ${ }^{50}$

Observe-se que, ao modificar o foco sobre o conceito de soberania, a Comissão deixou de lado a idéia clássica de soberania como significando internamente o monopólio do poder por uma autoridade central. $\mathrm{O}$ foco passou, em conseqüência, do direito

\footnotetext{
${ }^{48}$ Em inglês: International Commission on Intervention and State Sovereignty.

${ }^{49}$ ICISS. Responsibility to Protect, p. VIII.

${ }^{50}$ ICISS. Responsibility to Protect, p. 8.

Tradução livre, no original:

"to respect the dignity and basic rights of all the people within a state".
} 
de exercer, dentro de seu território, o poder de forma absoluta, ao dever de proteger aqueles que se encontram sob a jurisdição do Estado. Essa interpretação apresenta-se como o ponto central da argumentação proposta no relatório Responsabilidade de Proteger.

Nesse sentido, o relatório rejeita a tese do direito de ingerência por acreditar que tal teoria direciona o foco do debate a um direito que os Estados pertencentes à comunidade internacional teriam de intervir a fim de evitar graves violações de direitos humanos. No entender da Comissão, ao se falar, portanto, em direito de ingerência, a atenção volta-se para a ação interventora dos Estados e não para o fato de que há vidas a serem protegidas. Dessa forma, entendeu a Comissão que a discussão da questão a partir da teoria do direito de ingerência acabava por apresentar implicitamente uma conotação negativa. Assim sendo, era necessário a adoção de uma postura afirmativa dando preferência pela responsabilidade de proteger da comunidade internacional ao invés do direito de intervenção. $^{51}$

A construção da teoria da responsabilidade de proteger apresentada no relatório repousa sobre três fundamentos, quais sejam, "os princípios inerentes ao conceito de soberania, o impacto dos princípios emergentes de direitos humanos e de segurança humana, e as mudanças ocorridas nas práticas estatais e inter-governamentais". ${ }^{2}$ Esses três aspectos considerados pela Comissão são a seguir discutidos.

\footnotetext{
51 ICISS. The Responsibility to Protect: Report of the International Commission on Intervention and State Sovereignty. Toronto. IDRC, 2002, p. 11.

52 Ibidem, p. 12.

Tradução livre, no original: "the principles inherent in the concept of sovereignty; and secondly, the impact of emerging principles of human rights and human security, and changing state and intergovernmental practice."
} 


\subsubsection{O significado de soberania}

$\mathrm{O}$ atributo da soberania inerente aos Estados diante do quadro geral das relações internacionais é um conceito que, a partir da ordem instaurada com a Paz de Westfália, tem por base a idéia de que cada Estado possui o monopólio da autoridade sobre seu território. Desse entendimento decorre o princípio segundo o qual todos os Estados são juridicamente iguais no plano internacional, não importando as diferenças geográficas, econômicas ou políticas existentes entre os membros da comunidade internacional. Desse conceito decorre também o princípio da não-intervenção como desdobramento inevitável. De outro modo, ao se considerar que, no âmbito internacional, os Estados são iguais e soberanos, passa a ser uma decorrência lógica a proibição da intervenção nos assuntos internos de um Estado. O fato é que o princípio da igualdade soberana dos Estados, assim como o da nãointervenção foram consagrados pela Carta das Nações Unidas, que os afirma como princípios basilares e norteadores da ordem internacional. ${ }^{53}$

Diante desse quadro, argumenta a Comissão que a proliferação de tratados de proteção dos direitos humanos e a crescente vinculação dos Estados a esses documentos normativos internacionais gerou também a necessidade de se repensar a concepção westfaliana de soberania. ${ }^{54}$ Ao assumir compromissos internacionais, prossegue o argumento, o Estado não chega a ceder parte de sua soberania, mas apenas tem seu poder soberano modificado ou simplesmente exercita a soberania. A Comissão entende que o fato de o Estado

\footnotetext{
${ }^{53}$ CARTA DA ORGANIZAÇÃO DAS NAÇÕES UNIDAS

Artigo 2

A Organização e os seus membros, para a realização dos objetivos mencionados no Art $^{\circ}$. 1, agirão de acordo com os seguintes princípios:

1. A Organização é baseada no princípio da igualdade soberana de todos os seus membros;

$[\ldots]$

7. Nenhuma disposição da presente Carta autorizará as Nações Unidas a intervir em assuntos que dependam essencialmente da jurisdição interna de qualquer Estado, ou obrigará os membros a submeterem tais assuntos a uma solução, nos termos da presente Carta; este princípio, porém, não prejudicará a aplicação das medidas coercitivas constantes do capítulo VII.

${ }^{54}$ ICISS. The Responsibility to Protect: Report of the International Commission on Intervention and State Sovereignty. Toronto. IDRC, 2002, p. 13.
} 
ratificar um tratado acaba por engendrar uma transformação nas características de sua soberania, que deixaria de ser qualificada como controle e passaria a ser entendida como responsabilidade. Em outras palavras, ao assumir compromissos internacionais o Estado estaria assumindo uma responsabilidade perante a comunidade internacional no sentido de cumprir com as obrigações emanadas do tratado. ${ }^{55}$

De acordo com o relatório, o entendimento de soberania como responsabilidade tem sido crescentemente reconhecido nas relações internacionais e possui três significados. O primeiro deles refere-se ao fato de que as autoridades estatais passam a ser responsáveis pela proteção de seus cidadãos. Em segundo lugar, soberania como segurança sugere que "as autoridades políticas nacionais possuem responsabilidades perante os cidadãos internamente e perante a comunidade internacional, por meio da ONU, ${ }^{56}$ Por último, tal entendimento significa a possibilidade de que os agentes estatais sejam responsabilizados por suas ações ou omissões.

\subsubsection{A emergência dos princípios de direitos humanos}

O segundo pilar que permitiria a interpretação de soberania como responsabilidade diz respeito à relevância que tem sido conferida pela comunidade internacional ao tema dos direitos humanos. A promoção e proteção dos direitos humanos é um dos objetivos assumidos pela Organização das Nações Unidas e expresso na Carta da Organização. Além dos dispositivos que tratam do tema na Carta, outras convenções

\footnotetext{
55 ICISS. The Responsibility to Protect: Report of the International Commission on Intervention and State Sovereignty. Toronto. IDRC, 2002, p. 13.

${ }^{56}$ Ibidem, p. 13.

Tradução livre, no original: "the national political authorities are responsible to the citizens internally and to the international community through the UN".
} 
internacionais foram ratificadas por uma pluralidade de Estados, o que refletiria a preocupação crescente da comunidade internacional com a promoção do tema. ${ }^{57}$

A vinculação a tratados protetores de direitos humanos gera o comprometimento, cada vez maior, do Estado com o cumprimento das normas internacionais às quais aderiu. Esses compromissos, caso não sejam cumpridos, poderiam ter conseqüências negativas para o Estado no âmbito internacional. Esses desenvolvimentos são importantes na medida em que estabelecem novos padrões de comportamento e novos mecanismos de implementação dessas normas. ${ }^{58}$

Apesar desses argumentos, a Comissão entende que a forma mais eficaz de proteção aos direitos humanos continua sendo o aparato estatal do próprio país em que, eventualmente, sejam constatadas violações. As instâncias internacionais deveriam, portanto, ocupar um papel secundário na promoção e proteção dos direitos humanos, à qual se recorreria apenas quando esgotados os recursos domésticos. Na verdade, à exceção dos casos de intervenção externa, a implementação de sanções a violações de direitos humanos depende essencialmente dos governos nacionais.

\subsubsection{A prática estatal e intergovernamental}

O último fundamento da teoria da responsabilidade de proteger refere-se à intensificação do debate acerca das intervenções humanitárias. Ainda que não se possa reconhecer a existência de um direito internacional consuetudinário permitindo o uso da força para a proteção de direitos humanos, a Comissão entende que, desde a assinatura da Carta da ONU, pode-se verificar a emergência de práticas estatais e organizacionais que, se não criam

\footnotetext{
57 ICISS. The Responsibility to Protect: Report of the International Commission on Intervention and State Sovereignty. Toronto. IDRC, 2002, p. 14.

${ }^{58}$ Ibidem, p. 14.
} 
novos direitos, acedem os debates sobre o tema e contribuem para a formação de consensos em torno de um novo princípio de direito internacional. ${ }^{59}$

No entender da Comissão, as decisões do Conselho de Segurança somadas às práticas estatais e das organizações regionais estariam dando início ao princípio da responsabilidade de proteger. Tal princípio consubstanciar-se-ia no entendimento de que a intervenção militar com propósitos humanitários seria admissível nos casos em que graves violações estão sendo perpetradas ou são consideradas iminentes enquanto o Estado responsável pela proteção dessas pessoas não revela condições ou não demonstra interesse em protegê-las. ${ }^{60}$

$\mathrm{Na}$ esteira desse entendimento, a Comissão argumenta que a proibição ao uso da força prevista na Carta das Nações Unidas não deve ser compreendida de forma ampla quando se fala em graves violações de direitos humanos. O foco da discussão deveria, portanto, voltar-se para as questões envolvendo os propósitos, os meios, a exaustão de outros meios de solução, a proporcionalidade das medidas implementadas e o órgão com competência para autorizar a intervenção. ${ }^{61}$ A questão, para a Comissão, deixou de ser se é possível empreender uma intervenção humanitária com base na Carta da ONU, porquanto a resposta para essa indagação é afirmativa. Conseqüentemente, a discussão deve se concentrar nas questões procedimentais que envolvem tais operações. ${ }^{62}$

\subsection{Direito de ingerência versus responsabilidade de proteger}

\footnotetext{
59 ICISS. The Responsibility to Protect: Report of the International Commission on Intervention and State Sovereignty. Toronto. IDRC, 2002, p. 15.

${ }^{60}$ Ibidem, p. 16.

${ }^{61}$ Ibidem, p. 16.

${ }^{62}$ Ibidem, p. 16.
} 
A doutrina do direito de ingerência é refutada pela Comissão por motivos muito mais terminológicos do que de substância da teoria. De acordo com o relatório, falar em "direito de ingerência" ou em "direito de intervenção humanitária" não auxilia a causa por três razões: a) o foco volta-se para quem pratica a intervenção ou tem direito para tanto; b) negligencia-se outros aspectos importantes como a prevenção e a reconstrução; e c) autoriza a intervenção de forma peremptória. ${ }^{63}$

Entende a Comissão, portanto, que quando se fala em direito de ingerência a atenção direciona-se para o agente interventor e para seu suposto direito de intervir sempre que entender necessário. Tira-se, portanto, o foco das vítimas, isto é, daqueles que deveriam ser protegidos por meio da intervenção. O segundo ponto refere-se ao entendimento, compartilhado pela Comissão, de que intervenção humanitária não deve se restringir à ação em si, mas a um conjunto de medidas que abarcariam desde a prevenção das violações até a reconstrução dos locais onde houve danos em razão da intervenção. Por último, entende a Comissão que, ao se falar em direito de ingerência, estar-se-ia autorizando a intervenção antes de qualquer discussão acerca do caso concreto. Em outras palavras, por esse entendimento, o simples surgimento da violação geraria o direito de intervenção, antes mesmo de que se discutisse a possibilidade de implementação de outras medidas. ${ }^{64}$

Diante dessas considerações, a Comissão propõe a terminologia "responsabilidade de proteger" em substituição ao "direito de ingerência". Dessa forma, pretende-se: a) direcionar o foco para as pessoas que necessitam de proteção; b) ressaltar que a responsabilidade primária é do Estado; e c) abarcar as responsabilidades de reagir, prevenir

\footnotetext{
${ }^{63}$ ICISS. The Responsibility to Protect: Report of the International Commission on Intervention and State Sovereignty. Toronto. IDRC, 2002, p. 16.

${ }^{64}$ Ibidem, p. 16.
} 
e reconstruir. A Comissão entende, portanto, que essa mudança terminológica é importante porque evitaria a conotação negativa associado ao conceito de "direito de ingerência" ${ }^{65}$

Falar em responsabilidade de proteger implica, de acordo com o relatório, avaliar "as questões do ponto de vista daqueles que buscam ou precisam de apoio, ao invés daqueles que poderiam estar considerando empreender a intervenção." ${ }^{.66} \mathrm{O}$ termo também implicaria o entendimento de que a responsabilidade primária pertence ao Estado e, somente quando este não pode ou não possui meios para agir, é que a responsabilidade passa para a comunidade internacional. Por último, responsabilidade de proteger não significaria apenas o compromisso de reagir, mas também abarcaria as responsabilidades de prevenir crises humanitárias e de reconstruir as áreas afetadas. ${ }^{67}$

\subsection{Responsabilidade de prevenir}

A Comissão argumenta que parte da responsabilidade de proteger repousa sobre o entendimento de que essa responsabilidade se estende também para a capacidade de prevenir catástrofes humanitárias. Nesse sentido, seria de extrema importância, de acordo com o relatório, que medidas preventivas fossem adotadas em situações que possam provocar graves crises humanitárias. Essa responsabilidade seria, inicialmente, dos governos locais. Porém, para que a prevenção seja efetiva, muitas vezes, faz-se necessário o apoio da comunidade internacional, que pode ser proporcionada de diversas formas, em especial por meio de assistência ao desenvolvimento. A comunidade internacional pode ajudar, ainda, por meio do apoio às iniciativas locais que visam à promoção de "boa governança", dos direitos

\footnotetext{
${ }^{65}$ ICISS. The Responsibility to Protect: Report of the International Commission on Intervention and State Sovereignty. Toronto. IDRC, 2002, p. 17.

${ }^{66}$ Ibidem, p. 17.

Tradução livre, no original: "[...] the issues from the point of view of those seeking or needing support, rather than those Who may be considering intervention".

${ }^{67}$ Ibidem, p. 17.
} 
humanos, e de garantias de eficácia do estado de direito. Por meio dessas ações, a comunidade internacional ganharia maior credibilidade. ${ }^{68}$

Para que as medidas preventivas sejam eficientes, a Comissão argumenta que três condições essenciais devem ser cumpridas. A primeira delas refere-se à necessidade de early warning. A segunda condição diz respeito ao conhecimento das medidas disponíveis e à capacidade de bem avaliar cada uma delas a fim de determinar quais seriam as mais adequadas e eficazes na situação que se apresenta. Por último, seria necessária a existência de vontade política para, diante de uma situação de risco, atuar com a devida firmeza e determinação a fim de prevenir o desencadeamento de catástrofes humanitárias iminentes ou simplesmente em gestação. $^{69}$

A Comissão reconhece que um dos principais empecilhos à prevenção de crises está relacionado com o fato de os Estados serem, cada vez mais, relutantes em aceitar ajuda internacional preventiva. Tal relutância funda-se no medo de que a interferência externa transforme um problema doméstico em internacional ou simplesmente porque o governo no poder entende que seu prestígio seria abalado ao aceitar qualquer forma de ingerência externa. Diante disso, a Comissão aponta duas ordens de cuidados ou orientações a serem observadas. A primeira seria para que os dirigentes internacionais sejam sensíveis ao fato de que medidas preventivas podem ser intrusivas e que, portanto, deve-se optar, sempre que possível, por iniciativas que respeitem a soberania estatal. A segunda recomendação é voltada para os Estados que devem ser alertados para ao fato de que a resistência à ajuda internacional pode ser ainda mais prejudicial por aumentar as proporções da crise em gestação ao retardar o

\footnotetext{
${ }^{68}$ ICISS. The Responsibility to Protect: Report of the International Commission on Intervention and State Sovereignty. Toronto. IDRC, 2002, p. 19.

${ }^{69}$ Ibidem, p. 20.
} 
ingresso da ajuda externa. ${ }^{70} \mathrm{Na}$ esteira dessas considerações, a Comissão conclui que já é passado o tempo de se fomentar, no âmbito internacional, a cultura da prevenção. Dessa forma, evitar-se-ia perdas humanas a um custo político e econômico mais baixo. ${ }^{71}$

\subsection{Responsabilidade de reagir}

Fracassadas as medidas preventivas, surgiria a responsabilidade de reagir, ou seja, de empreender a intervenção com o propósito de evitar graves crises humanitárias. A Comissão considera intervenção não apenas aquela que envolve a utilização da força militar, mas também as que envolvem medidas políticas ou econômicas. Contudo, como já foi dito, por serem as intervenções militares as que efetivamente geram controvérsias, o relatório dedica maior atenção a esse tipo de intervenção. ${ }^{72}$

A primeira questão que surge, quando se pensa a respeito do tema das intervenções, refere-se às circunstâncias nas quais seria possível, ou adequado, intervir militarmente. A Comissão argumenta que a força militar deve ser utilizada apenas em casos extremos, como último recurso, e estabelece seis critérios por meio dos quais as propostas de intervenção devem ser avaliadas ao se tomar decisão nesse sentido: autoridade competente; justa causa; intenção correta; último recurso; meios proporcionais e prospecções razoáveis.

\subsubsection{Autoridade competente}

Autoridade competente, a que se refere a Comissão, diz respeito ao órgão com legitimidade para autorizar uma intervenção humanitária. Entende-se que a instituição com autoridade para tal empreendimento seria a própria Organização das Nações Unidas, mais especificamente, o Conselho de Segurança das Nações Unidas (CSNU) seria o órgão

\footnotetext{
${ }^{70}$ ICISS. The Responsibility to Protect: Report of the International Commission on Intervention and State Sovereignty. Toronto. IDRC, 2002, p. 27.

71 Ibidem, p. 27.

${ }^{72}$ Ibidem, p. 29.
} 
com competência primária para determinar uma intervenção militar. Em caso de paralisação do CSNU em razão da ameaça do uso do mecanismo de veto por parte um dos países do P-5, poderia a Assembléia Geral das Nações Unidas emitir recomendações que, no entanto, não possuem caráter cogente, sendo apenas sugestões ou sanções morais, que podem, ou não, ser cumpridas pelos Estados. $^{73}$

O relatório aponta para a importância da atuação do CSNU, sobretudo nos casos de maior repercussão, porquanto a omissão nesses casos desencadearia duas conseqüências negativas. A primeira delas seria o aumento da pressão internacional no sentido da atuação unilateral por parte de uma grande potência, mesmo que sem autorização do Conselho. A segunda conseqüência seria a corrosão da legitimidade do CSNU e da própria Organização, uma vez que a instituição se mostraria incapaz de lidar com os desafios que se lhe apresentam. ${ }^{74}$

\subsubsection{Justa causa}

O segundo critério apontado pela Comissão diz respeito à justeza da causa entendida como a motivação da intervenção. De acordo com o relatório, as intervenções militares com propósitos humanitários devem ser empreendidas apenas como último recurso, e apenas em casos extremos. Duas seriam as circunstâncias que autorizariam a utilização de tal medida. A primeira circunstância seria aquela em que se está, claramente, diante do perigo de perda de vidas em larga escala, seja esse perigo atual ou iminente, com intenções genocidas ou não, provocados por uma ação ou por uma omissão do Estado, ou nos casos em que se configure a situação de Estado falido. A segunda circunstância seria caracterizada pela

\footnotetext{
73 ICISS. The Responsibility to Protect: Report of the International Commission on Intervention and State Sovereignty. Toronto. IDRC, 2002, p. 48.

${ }^{74}$ Ibidem, p. 55.
} 
existência de ações voltadas para limpezas étnicas, corrente ou iminente, promovidas por matança, expulsão ou por atos de terror ou estupro. ${ }^{75}$

Deve-se ressaltar o entendimento da Comissão segundo o qual se poderia falar no uso da intervenção militar de forma antecipada, ou seja, antes mesmo que a crise tenha sido desencadeada. Caso contrário, "a comunidade internacional colocar-se-ia em uma posição moralmente insustentável de ter que esperar até que o genocídio comece, para, então ser capaz de atuar para detê-lo",76.

\subsubsection{Intenção correta}

A Comissão argumenta que o objetivo precípuo da intervenção deve ser a proteção humanitária. Dessa forma, a "intenção correta" está ligada às intenções do Estado interventor. De acordo com o relatório, aquele que se propõe a atuar militarmente deve ter por objetivo, primário, evitar o sofrimento humano. ${ }^{77}$

Considerando que os Estados tendem a atuar de acordo com seus interesses nacionais, parece um tanto utópico acreditar que os Estados que conduzem uma intervenção empreguem custosos recursos militares e econômicos se não tiverem outros interesses além da proteção dos direitos humanos em si mesma. Assim, a Comissão propõe que as intervenções humanitárias ocorram sempre de forma coletiva. Desse modo, a sobreposição de interesses nacionais sobre a proteção humanitária seria reduzida consideravelmente. ${ }^{78}$ Outro recurso importante para se evitar essa situação seria a obtenção do apoio popular do local onde se procederia a intervenção. Ademais, a Comissão argumenta que, dado o grau de

\footnotetext{
${ }^{75}$ ICISS. The Responsibility to Protect: Report of the International Commission on Intervention and State Sovereignty. Toronto. IDRC, 2002, p. 32.

${ }^{76}$ Ibidem, p. 33.

Tradução livre, no original: "the international community would be placed in the morally untenable position of being required to wait until genocide begins, before being able to take action to stop it".

77 Ibidem, p. 36.

${ }^{78}$ Ibidem, p. 36.
} 
interdependência do mundo atual, é questionável o entendimento segundo o qual crises em locais distantes não geram conseqüências em outras partes do globo. A tendência é a de que conflitos, mesmo em lugares longínquos, produzam resultados negativos como levas de refugiados, terrorismo, tráfico de entorpecentes, entre outros efeitos nos demais Estados. ${ }^{79}$

\subsection{4 Último recurso}

O critério do último recurso diz respeito ao entendimento de que a intervenção militar deve ser sempre o último recurso a ser utilizado. Antes de lançar mão desse recurso, as medidas de prevenção ou de solução pacífica de controvérsias devem ser exploradas. Porém, isso não significa que cada uma das medidas deve ter sido implementada antes de uma intervenção militar visto que podem haver situações nas quais simplesmente não haverá tempo hábil para isso.

\subsubsection{Meios proporcionais}

De acordo com o relatório, a intervenção militar deve ser utilizada de forma mínima, apenas com a intensidade necessária aos propósitos humanitários. “Os meios devem estar de acordo com os fins e em consonância com a magnitude da provocação original". ${ }^{80}$ Ademais, a Comissão assevera que as intervenções militares devem, obviamente, atuar de acordo com as regras de direito internacional humanitário.

\subsubsection{Prospecções razoáveis}

Sobre o último critério, a Comissão argumenta que as intervenções militares somente devem ser realizadas quando houver chances razoáveis de sucesso. Isso significa que apenas quando houver possibilidades razoáveis de se conseguir evitar maiores sofrimentos

\footnotetext{
${ }^{79}$ ICISS. The Responsibility to Protect: Report of the International Commission on Intervention and State Sovereignty. Toronto. IDRC, 2002, p. 36.

${ }^{80}$ Ibidem, p. 37.

Tradução livre, no original: "The means have to be commensurate with the ends, and in line with the magnitude of the original provocation".
} 
humanos é que a intervenção militar deve ser empregada. Desse modo, nas situações em que haja riscos elevados de que os danos causados por uma possível intervenção militar sejam potencialmente maiores do que os provocados pela própria crise, a implementação de uma operação militar deve ser evitada. ${ }^{81}$ Nesse sentido, a Comissão argumenta que não seriam possíveis intervenções humanitárias praticadas contra um dos cinco membros permanentes do Conselho de Segurança das Nações Unidas. O mesmo ocorre com outras potências que não são membros permanentes do CSNU. Contudo, tal entendimento não pode ser utilizado para afastar a possibilidade de intervenções humanitárias em outros Estados. ${ }^{82}$

\subsection{Responsabilidade de reconstruir}

O último estágio da responsabilidade de proteger corresponde à responsabilidade de reconstruir. Isso significa que se uma intervenção militar é implementada, deve haver "um comprometimento genuíno com o auxílio à reconstrução de uma paz durável, e com a promoção da boa governança e do desenvolvimento sustentável" ${ }^{83} \mathrm{O}$ objetivo dessa estratégia, segundo o relatório, é evitar que a situação que deu causa à intervenção não volte a ocorrer. $^{84}$

Nesse sentido, a Comissão entende que há três áreas para as quais os esforços de reconstrução devem estar voltados, quais sejam, segurança, justiça e desenvolvimento econômico. A primeira preocupação visa a proporcionar segurança à população dentro do território, de modo a evitar que atos de vingança provoquem uma nova crise. A segunda diz respeito à criação de um sistema judiciário que funcione de modo

\footnotetext{
${ }^{81}$ ICISS. The Responsibility to Protect: Report of the International Commission on Intervention and State Sovereignty. Toronto. IDRC, 2002, p. 37.

${ }^{82}$ Ibidem, p. 37.

${ }^{83}$ Ibidem, p. 39.

Tradução livre, no original: "there should be a genuine commitment to helping to build a durable peace, and promoting good governance and sustainable development."

${ }^{84}$ Ibidem, p. 39.
} 
apropriado, uma vez que é de extrema importância para a manutenção da ordem no interior desses Estados. O terceiro tópico da responsabilidade de reconstruir refere-se à necessidade da implementação de medidas que encorajem a criação de instituições voltadas à promoção do crescimento econômico.

\subsection{Considerações finais}

De modo geral, o relatório Responsabilidade de Proteger apresenta tese a favor das intervenções humanitárias fundada na concepção de soberania como responsabilidade. Essa nova acepção do instituto da soberania seria possível, de acordo com o documento, uma vez que se percebe no âmbito internacional uma crescente preocupação com a proteção dos direitos humanos e uma intensificação da vinculação dos Estados a tratados internacionais.

Assim, de acordo com a ICISS, a questão principal não mais se refere à discussão a respeito da legitimidade das intervenções, mas sim à forma como essas intervenções devem ocorrer e quem teria competência para autorizar tais iniciativas. Nesse sentido, o relatório ressalta que a responsabilidade primária de proteger seus cidadãos é do Estado, porém, no caso da incapacidade desse Estado, a comunidade internacional torna-se responsável por essa proteção e essa atuação internacional deve-se ser autorizada pelo CSNU. 


\section{RESPONSABILIDADE DE PROTEGER: RETÓRICA OU REALIDADE?}

O relatório Responsabilidade de Proteger, certamente, apresentou uma nova roupagem à teoria das intervenções humanitárias. No presente capítulo pretende-se, inicialmente, apresentar, ainda que de forma breve, a noção tradicional de soberania para, em seguida, examinar o novo enfoque sugerido pelo relatório e analisar alguns questionamentos que surgem a partir da tese proposta.

$\mathrm{O}$ argumento utilizado pela Comissão Internacional sobre Intervenção e Soberania Estatal que justificaria as intervenções com fins humanitários funda-se, como apresentado no capítulo anterior, na concepção de soberania como responsabilidade. Esse entendimento esteia-se na visão de que o conceito clássico de soberania não corresponde mais à realidade atual, de que há uma preocupação crescente, por parte da sociedade internacional, com a proteção e promoção dos direitos humanos, e de que há um relativo consenso internacional voltada para a proteção humanitária. Nesse sentido, a ICISS busca apresentar a concepção de soberania sob um novo enfoque, a fim de conciliar esses novos aspectos da realidade. $^{85}$

\subsection{A concepção clássica de soberania}

Em sua concepção clássica, herdada dos pensadores da ciência da política desde Hobbes e Bodin, a soberania apresenta duas faces: a externa e a interna. A soberania

\footnotetext{
${ }^{85}$ ICISS. The Responsibility to Protect: Report of the International Commission on Intervention and State Sovereignty. Toronto. IDRC, 2002, p. 13.
} 
estatal sob a perspectiva externa significa a inexistência de uma autoridade que se sobreponha ao poder dos Estados. Em outras palavras, reconhecer os Estados como entes soberanos implica reconhecer a inexistência de uma entidade supranacional. Desse entendimento, decorre, portanto, que os Estados, por serem todos soberanos, seriam iguais e autônomos no âmbito internacional. Como conseqüência lógica, a regra básica da convivência entre as soberanias seria a da não-intervenção em assuntos domésticos. ${ }^{86}$

No âmbito interno, soberania significa o poder de controlar a sociedade e as instituições na esfera doméstica. Assim, decorre da condição soberana do Estado o poder, por exemplo, de editar leis e de impor seu cumprimento. Esse poder pode ser exercido de forma centralizada ou descentralizada cabendo, porém, ao Estado definir as regras que o regerão, não havendo outra instância de poder com competência para interferir no exercício dessa prerrogativa. Dessa forma, em sua concepção clássica, soberania, sob o ponto de vista interno, significa o controle sobre a ação das pessoas dentro de seus limites territoriais.

\subsection{Soberania condicionada?}

Entende a Comissão que essa visão clássica de soberania vinculada a controle estaria em dissonância com a atual realidade internacional. Dessa forma, no relatório, a ICISS propõe uma mudança de enfoque. Ao invés de se analisar a soberania interna com o foco nos Estados e no "direito" de controle que estes exercem sobre seus jurisdicionados, a Comissão propõe que a analise seja realizada a partir das "responsabilidades" que o Estado possuiria diante de seus cidadãos. Em outras palavras, deixar-se-ia de lado os direitos dos Estados sobre seus territórios e voltar-se-ia para os deveres estatais para com sua própria

\footnotetext{
${ }^{86}$ FABRI, Hélène Ruiz. "Human rights and state sovereignty”. In: ALSTON, Philip e MACDONALD, Euan (orgs.). Human Rights, Intervention and the Use of Force. Nova York: Oxford Univesity Press, 2008, p. 34.
} 
população. Desse modo, a soberania interna passaria a priorizar a responsabilidade ao invés do exercício do controle. ${ }^{87}$

De acordo com Alex J. Bellamy, a visão de soberania como responsabilidade já havia sido desenvolvida anteriormente por ocasião de estudos realizados acerca das IDPs - Internally Displaced People. As pessoas nessas condições, por permanecerem dentro das fronteiras estatais, acabavam não gozando de nenhuma proteção internacional, como aquelas concedidas, por exemplo, aos refugiados. Dessa forma, um dos principais desafios que se apresentou aos encarregados do estudo, foi o de convencer os governos locais a proteger essas pessoas. A grande dificuldade para convencer esses governos decorria do fato de que eram os próprios governos os causadores do sofrimento. ${ }^{88}$

Ante essa situação, elaborou-se o argumento da soberania como responsabilidade, voltado para as IDPs. $O$ ponto de partida dessa concepção era o reconhecimento de que os governos locais possuíam uma responsabilidade primária de proteger essas pessoas e nos casos em que o Estado não possuísse capacidade para levar essa tarefa, dever-se-ia solicitar assistência internacional. Essa ajuda seria empreendida no sentido de assumir as responsabilidades primárias do Estado. Nesse sentido, frente a uma crise de largas proporções, o Estado poderia, ou melhor, deveria aceitar a assistência internacional e trabalhar em conjunto diante do risco de se fechar à ajuda exterior e deixar que a situação piorasse, o que inevitavelmente ocasionaria uma corrosão significativa, em termos de legitimidade soberana, para o Estado. ${ }^{89}$

\footnotetext{
${ }^{87}$ ICISS. The Responsibility to Protect: Report of the International Commission on Intervention and State Sovereignty. Toronto. IDRC, 2002, p.VIII.

88 BELLAMY, Alex J. "The responsibility to protect and the problem of military intervention". In: International Affairs, 84/4, 2008, 619.

${ }^{89}$ Ibidem, 619.
} 
A partir desse entendimento, a ICISS formula a tese da legitimidade das intervenções humanitárias. Uma vez que a soberania interna estaria condicionada ao cumprimento de deveres estatais, a inobservância dessas responsabilidades implicaria conseqüências também na face externa da soberania. Isso porque, entende a Comissão, a responsabilidade de proteger é, primariamente, estatal, porém, na falha do Estado, essa responsabilidade passaria à comunidade internacional. Assim afirma a Comissão:

Responsabilidade de proteger é a idéia de que os Estados soberanos possuem a responsabilidade de proteger seus cidadãos de evitáveis catástrofes — de assassinatos e estupros em massa, da fome - mas quando os Estados não desejam ou não possuem capacidade para tanto, essa responsabilidade deve ser assumida pela comunidade de Estados..$^{90}$

Assim, pode-se argumentar que a soberania estatal estaria condicionada ao cumprimento, por parte do Estado, de deveres para com seus cidadãos. Da inobservância dessas obrigações decorreria a legitimidade para se intervir. Isso porque, a responsabilidade de proteger, ainda que seja voltada para o âmbito doméstico, seria um compromisso assumido internacionalmente pelos Estados a partir da ratificação da Carta das Nações Unidas.

De acordo com a ICISS, ao aderir à Carta da ONU, o Estado estaria assumindo as responsabilidades decorrentes da ratificação do referido tratado e o processo de ratificação significa, em sua essência, a internalização de direitos e obrigações decorrentes da assinatura soberana de tratados internacionais. Em outras palavras, o Estado estaria se comprometendo a agir de acordo com os princípios enunciados na Carta, dentre os quais está o princípio do artigo 1.3, o qual estabelece que um dos propósitos da ONU é a promoção e

\footnotetext{
${ }^{90}$ ICISS. The Responsibility to Protect: Report of the International Commission on Intervention and State Sovereignty. Toronto. IDRC, 2002, p. VIII.

Tradução livre, no original: "Responsibility to Protect is the idea that sovereign states have a responsibility to protect their own citizens from avoidable catastrophe - from mass murder and rape, from starvation - but that when they are unwilling or unable to do so, that responsibility must be borne by the broader community of states."
} 
proteção dos direitos humanos. ${ }^{91}$ Assim, afirma a Comissão, ao se tornar membro das Nações Unidas o Estado é recepcionado pela comunidade internacional como um novo membro responsável e o Estado, por sua vez, ao ratificar a Carta, aceita suas responsabilidades. ${ }^{92}$ No entanto, a Comissão assevera que isso não significaria a "transferência ou diluição da soberania estatal", mas apenas uma nova interpretação desse atributo, que passa de soberania como controle para soberania como responsabilidade. ${ }^{93}$

Ademais, a ICISS, a fim de dar mais robustez à sua tese, afirma haver uma prática internacional favorável às intervenções militares para fins humanitários. Mesmo reconhecendo não haver um direito consuetudinário internacional permitindo tais intervenções, a Comissão argumenta existir uma prática estatal emergente no sentido de legitimar as intervenções humanitárias. Essa prática, somada às normas de direito internacional que versam sobre direitos humanos levam a ICISS a concluir que haveria uma responsabilidade de proteger por parte da comunidade internacional. ${ }^{94}$ Assim afirma o relatório:

o ponto é simplesmente que existe um amplo e cumulativo corpo de normas e práticas que apóiam a noção segundo a qual, não importa de que forma o exercício dessa responsabilidade se dará, os membros da vasta comunidade de Estados de fato possuem a responsabilidade de proteger não apenas seus cidadãos, mas também os dos outros Estados. ${ }^{95}$

\footnotetext{
${ }^{91}$ CARTA DAS NAÇÕES UNIDAS
}

Artigo 1 - Os propósitos das Nações Unidas são:

3. Conseguir uma cooperação internacional para resolver os problemas internacionais de caráter econômico, social, cultural ou humanitário, e para promover e estimular o respeito aos direitos humanos e às liberdades fundamentais para todos, sem distinção de raça, sexo, língua ou religião; e

92 ICISS. The Responsibility to Protect: Report of the International Commission on Intervention and State Sovereignty. Toronto. IDRC, 2002, p. 13.

Nas palavras do relatório: "In the one hand, in granting membership of the UN, the international community welcomes the signatory state as a responsible member of the community of nations. On the other hand, the state itself, in signing the Charter, accepts the responsibilities of membership flowing from that signature."

${ }^{93}$ Ibidem, p. 13.

${ }^{94}$ Ibidem, p. 15-16.

${ }^{95}$ Ibidem, p. 16.

Tradução livre, no original: "[...] the point is simply that there is a large and accumulating body of law and practice which supports the notion that, whatever form the exercise of that responsibility may properly take, 
De um modo geral, portanto, como aponta Edward C. Luck, o relatório Responsabilidade de Proteger sugere que os Estados possuem o compromisso de proteger seus cidadãos, que a comunidade internacional possui uma responsabilidade secundária e que tal responsabilidade deve ser levada a cabo, quando necessário, pelo Conselho de Segurança das Nações Unidas. Assim, a ICISS propõe que a existência de justa causa justificaria o uso da força além das duas hipóteses permitidas pela Carta da ONU. ${ }^{96}$

\subsection{Responsabilidade de proteger e intervenções humanitárias: implicações}

A noção de soberania como responsabilidade é apoiada por autores como Fernando Tesón. De acordo com o autor, o Estado tem como finalidade maior a proteção e a promoção dos direitos humanos de seus cidadãos. No seu entendimento tais direitos decorrem da própria condição humana. A soberania seria, portanto, um mero instrumento, por meio do qual o Estado alcançaria seus desígnios. ${ }^{97}$ Assim, Tesón afirma que "governos e outros no poder que seriamente violam esses direitos derrubam a única razão que justifica seu poder político, e, dessa forma, não deveriam ser protegidos pelo direito internacional. ${ }^{, 98}$ Soberania não poderia, portanto, ser entendida como um fim em si mesma, mas sim como um instrumento, que só tem sentido se utilizada para a finalidade maior do Estado. Logo, como afirma Tesón, a "soberania possui finalidades humanas valiosas, e aqueles que gravemente as violam não se podem esconder atrás do princípio da soberania. Tirania e anarquia

members of the broad community do have a responsibility to protect both their own citizens and those of other states as well."

${ }^{96}$ LUCK, Edward C. "The Responsible Sovereign and the Responsibility to Protect”. In: MÜLLER, Joachim W. e SAUVANT, Karl P. (eds.). Annual Review of United Nations Affairs. Nova York: Oxford University Press, 2008, pp. xxxiii-xliv.

97 TESÓN, Fernando R. "The liberal case for humanitarian intervention". In: HOLZGREFE, J. L. e KEOHANE, Robert O. Humanitarian intervention: ethical, legal, and political dilemmas. Cambridge: Cambridge University Press, 2003, p. 93.

${ }^{98}$ Ibidem, p. 93.

Tradução livre, no original: "Governments and others in power who seriously violate those rights undermine the one reason that justifies their Power, and thus should not be protected by international law." 
causam o colapso da soberania". ${ }^{99}$ Assim, Tesón afirma que, no limite, a invasão norteamericana ao Iraque, em 2003, seria justificável nos termos da responsabilidade de proteger.

Por outro lado, da leitura de artigos relacionados ao tema, verifica-se a existência de diversas críticas à concepção responsabilidade de proteger e, de modo geral, à tese das intervenções humanitárias. Uma dessas críticas diz respeito à preocupação de que aceitar a legitimidade das intervenções militares com propósitos humanitários poderia ameaçar a segurança da ordem internacional. Nicholas Wheeler, apresenta várias razões que geralmente fundamentam as críticas com relação às intervenções humanitárias. Essas razões são construídas basicamente a partir da visão realista das relações internacionais que considera que o que motivaria a ação estatal no cenário internacional seria o interesse nacional e o poder, sendo improvável que a noção de responsabilidade em relação a questões humanitárias pudessem suplantar as preocupações com o poder e o interesse nacional. ${ }^{100}$

Assim, considerando que os Estados atuam internacionalmente de acordo com seus interesses nacionais, legalizar um direito à intervenção humanitária permitiria que os Estados fizessem uso abusivo desse argumento, isto é, o utilizassem para seus próprios propósitos políticos. Essa corrente de interpretação reitera que a soberania é um dos pilares essenciais da ordem internacional e reconhecer princípios morais capazes de passar por cima dessa base poderia gerar insegurança e incerteza no cenário internacional. Isso porque intervenções militares com propósitos de conquista e expansão poderiam ser empreendidas

99 TESÓN, Fernando R. "The liberal case for humanitarian intervention". In: HOLZGREFE, J. L. e KEOHANE, Robert O. Humanitarian intervention: ethical, legal, and political dilemmas. Cambridge: Cambridge University Press, 2003, p. 93.

Tradução livre, no original: "Sovereignty serves valuable human ends, and those who grossly assault them should not be allowed to shield themselves behind the sovereignty principle. Tyranny and anarchy cause the moral collapse of sovereignty".

${ }^{100}$ WHEELER, Nicholas J. Saving strangers: humanitarian intervention in international society. Nova York: Oxford University Press, 2000, p. 29. 
sob o manto das intervenções humanitárias e, nesse ambiente, a ordem internacional estaria ameaçada pela imprevisibilidade das ações estatais. ${ }^{101}$

Um segunda corrente crítica, que Wheeler define como descritiva, afirma que os Estados somente praticariam a intervenção quando interesses vitais estiverem em jogo. Os Estados não colocariam em jogo a vida de seus soldados ou altas somas de recursos se, em contrapartida, não houver ganhos significativos que justifiquem o esforço. Em outras palavras, o pressuposto é o de que os Estados agem de acordo com seus interesses e somente intervirão quando houver ganhos políticos ou econômicos relevantes. Nesse sentido, as intervenções seriam levadas a cabo por outros motivos que não a simples intenção de proteger populações perseguidas ou promover direitos humanos, mas sim para alcançar interesses nacionais. $^{102}$

Outra crítica que se faz às intervenções humanitárias a partir da visão realista é a de que existe uma tendência de que as intervenções ocorram de forma seletiva, ou seja, os Estados somente empreenderiam uma intervenção militar nos casos em que tivessem vislumbrado claras possibilidades de ganhos. Assim, legitimar as intervenções humanitárias aumentaria as chances de que os Estados aplicassem essa regra sempre de forma seletiva. $\mathrm{O}$ problema dessa seletividade, afirma Wheeler, "surge quando um princípio moral está em jogo em mais de uma situação, mas os interesses nacionais ditam respostas divergentes". ${ }^{103}$ Em outras palavras, o fato de os Estados agirem conforme seus interesses nacionais acabaria por colocar a credibilidade do sistema.

\footnotetext{
${ }^{101}$ WHEELER, Nicholas J. Saving strangers: humanitarian intervention in international society. Nova York: Oxford University Press, 2000, p. 29.

102 Ibidem, p. 30.

${ }^{103}$ Ibidem, 2000, p. 31.

Tradução livre, no original: "The problem of selectivity arises when an agreed moral principle of at stake in more than one situation, but national interest dictates a divergence of response."
} 
A última corrente apresentada por Wheeler adota posicionamento bastante extremo uma vez que defende o argumento segundo o qual crises humanitárias é um problema que diz respeito apenas ao Estado envolvido. Nesse entendimento, os membros da comunidade internacional não teriam o direito de intervir porquanto os cidadãos são de responsabilidade exclusiva dos Estados sob a autoridade do qual vivem. Essa visão extremada, argumenta o autor, defende que a única hipótese que justificaria arriscar a vida de seus soldados numa intervenção em outro país seria em defesa do interesse nacional. ${ }^{104}$

Além dessas críticas apresentadas por Nicholas Wheeler, há aqueles que são contra intervenções humanitárias por questões relacionadas à utilização das forças armadas em si. Iain Atack os denomina pacifistas e afirma que os filiados a essa corrente suspeitam do uso da força em qualquer circunstância. Entendem que a intervenção militar, inevitavelmente, traz conseqüências não-humanitárias uma vez que envolve a luta armada. ${ }^{105}$ Há, ainda, criticas referentes, especificamente, à Responsabilidade de Proteger. Essas críticas se baseiam nos acontecimentos recentes no cenário internacional, em especial, com relação à crise humanitária que se arrasta no Sudão desde 2003. De acordo com Paul D. Williams e Alex J. Bellamy, a análise da crise em Darfur leva a crer que esse seria um caso ao qual seria perfeitamente aplicável a responsabilidade de proteger. Porém, a comunidade internacional não tem atuado a contento, deixando clara a discrepância entre as teorias formuladas acerca das intervenções humanitárias e a prática estatal. ${ }^{106}$

\subsection{Considerações finais}

\footnotetext{
${ }^{104}$ WHEELER, Nicholas J. Saving strangers: humanitarian intervention in international society. Nova York: Oxford University Press, 2000, p. 31.

${ }^{105}$ ATACK, Iain. "Ethical objections to humanitarian intervention.” In: Ethics of Humanitarian Intervention, Vol. 33(3): 279-292, p. 289.

${ }^{106}$ BELlaMY, Alex J. e WILliAMS, Paul D. The Responsibility to protect and the crisis in Darfur. In: Security Dialogue, 2005, 36, 27, p. 29.
} 
O relatório apresentado pela Comissão Internacional sobre Intervenção e Soberania Estatal busca apresentar uma nova face para a teoria das intervenções humanitárias. Porém, considerando as críticas que surgem com relação à tese da responsabilidade de proteger, verifica-se que existe uma preocupação de alguns setores da comunidade internacional com a questão da proteção humanitária, no entanto, essa preocupação é, ainda, bastante incipiente. Os Estados parecem continuar atuando, no cenário internacional, de acordo com seus interesses nacionais. O que se verifica é que, dada a maior ligação entre os vários rincões do globo, uma crise humanitária que afeta um local distante pode ser alvo de intervenção se a referida crise conseguir mobilizar a opinião pública de um Estado com condições de intervir. Em tais circunstâncias, poder-se-ia vislumbrar determinado membro da comunidade internacional atuando em defesa dos nacionais de outro Estado. Em outras situações, não parece haver vontade política para tanto. 


\section{CONCLUSÃO}

Como visto ao longo do trabalho, o tema das intervenções é bastante controverso porque levanta questões referentes a conceitos caros às relações internacionais. De um lado, está o princípio da soberania dos Estados, norteador da própria natureza das relações internacionais há mais de três séculos e um dos pilares do direito internacional. É a partir da concepção de que os Estados são soberanos que decorrem os princípios da nãointervenção e da igualdade jurídica dos Estados. De outro lado, está a preocupação com a proteção dos direitos humanos, a qual é construída com base em valores morais também muito caros à própria idéia de civilização.

No primeiro capítulo viu-se que a teoria das intervenções humanitárias tem sua gênese na teoria da guerra justa. Esta fundava-se, inicialmente, em pressupostos religiosos. Considerava-se justa a guerra empreendida dentro dos preceitos do Cristianismo. Em seguida, tal teoria recebe uma roupagem secular. Hugo Grotius, um dos principais pensadores do tema, entendia ser justa a guerra realizada para proteger os súditos em outros Estados. Baseava-se, o jurista holandês, na concepção de que toda pessoa possuía direitos inerentes à sua condição humana e esses direitos deveriam ser respeitados por todos.

Com o passar dos anos, percebe-se, entretanto, que a preocupação crescente com a positivação do direito internacional tornava mais difícil manejar e reivindicar direitos apenas no plano político. Sobretudo no século XX, diante das enormes tragédias pelas guerras observa-se um esforço no sentido de proibir a guerra como meio legítimo de solução de 
controvérsias. Na esteira desse pensamento, alguns instrumentos normativos internacionais são firmados na tentativa de tolher o recurso à guerra. Essa preocupação é expressa na Carta das Nações Unidas, a qual proíbe o uso da força de forma peremptória, admitindo apenas duas exceções, quais sejam, legítima defesa e autorização do Conselho de Segurança.

Ocorre que, em especial, a partir das últimas décadas do século passado, percebe-se uma preocupação com as questões humanitárias que surgem nas mais diferentes regiões do globo e se avolumam. Essas preocupações se refletem nas diversas teses que sustentariam a legitimidade de intervenções militares para fins humanitários. É na esteira dessas preocupações que é elaborado, já no século XXI, o relatório Responsabilidade de Proteger. Como visto, tal documento busca angariar subsídios para fundamentar a legitimidade das intervenções humanitárias. A questão central apresentada pelo relatório é a introdução no direito internacional da concepção de soberania como responsabilidade, elaborada a partir da visão de que a realidade atual não mais permitiria que o instituto da soberania fosse entendido simplesmente como controle mas que deveria incluir também ou até ser substituído pela noção de responsabilidade. Nesse sentido, o documento argumenta que a responsabilidade primária de proteger repousaria sobre o Estado. Porém, sempre que um Estado falha nessa proteção, tal responsabilidade passa à comunidade internacional.

Dessa forma, a Comissão, que elaborou o relatório, entende que a discussão não deve mais se concentrar na legitimidade ou não das intervenções, mas sim na forma como essa intervenção deve-se dar. A ICISS afirma que o órgão com competência para autorizar intervenções militares para fins humanitários seria o próprio Conselho de Segurança da ONU. A Comissão tenta, ainda, delinear alguns padrões a partir dos quais a intervenção deveria ocorrer: justa causa, intenção correta, prospecção positiva, meios razoáveis e último recurso. 
No entanto, como apontam alguns críticos, ainda que se perceba preocupações com relação à proteção das pessoas humanas em casos de crises humanitárias, percebe-se, também, que há uma preocupação com relação às conseqüências que a legitimação das intervenções humanitárias poderiam trazer para as relações internacionais. Tais críticas são elaboradas, sobretudo, a partir da teoria realista das relações internacionais. Para os teóricos dessa corrente, os Estados agem de acordo com seus interesses nacionais, logo, a legitimidade do discurso humanitário poderia gerar abusos. Ademais, a tendência é que os Estados empreendam intervenção somente quando se lhes apresentarem ganhos consideráveis.

Assim, pode-se concluir que o relatório Responsabilidade de Proteger traz algumas contribuições relevantes para a doutrina da intervenções humanitárias, em especial, a questão da soberania como responsabilidade. Não há como se negar que a preocupação com os direitos humanos tem-se intensificado nos últimos anos. A questão é: teria essa preocupação se intensificado o suficiente para modificar o padrão de comportamento dos Estados? Parece que não. A despeito da proliferação de teses exaltando a responsabilidade de proteger, a julgar pelo caso de Darfur, muito pequena parece ser a influência dessas idéias sobre a prática dos Estados.

Em face das limitações próprias de um trabalho monográfico, não foi possível explorar em detalhes muitos dos aspectos tratados em especial a complexidade da relação entre o princípio da soberania e as questões humanitárias que tocam fundo os valores que nortearam a formação das sociedades modernas. Também não foi possível explorar toda a riqueza de uma análise em profundidade dos argumentos contidos no relatório Responsabilidade de Proteger produzido no âmbito das Nações Unidas cuja importância e atualidade são indiscutíveis para o campo de estudo das Relações Internacionais. A intenção é 
que no futuro, um trabalho mais alentado e completo possa apresentar um balanço mais compreensivo das tendências na abordagem da questão das intervenções humanitárias por parte dos Estados e das instâncias internacionais. 


\section{REFERÊNCIAS BIBLIOGRÁFICAS}

AREND, Anthony Clark; BECK, Robert J. International law and the use of force. New York: Routledge, 1993.

ATACK, Iain. "Ethical objections to humanitarian intervention." In: Ethics of Humanitarian Intervention, Vol. 33(3): 279-292.

BELLAMY, Alex J. "The responsibility to protect and the problem of military intervention". In: International Affairs, 84/4, 2008, 619.

. e WHEELER, Nicholas. "Humanitarian intervention in world politics". In: BAYLIS, J. e SMITH, S (org.). The Globalization of world politics: An Introduction to international relations. Nova York: Oxford Univesity Press, 2005.

. e WILLIAMS, Paul D. The Responsibility to protect and the crisis in Darfur. In:

Security Dialogue, 2005, 36, 27.

BROWNLIE, Ian. International law and the use of force by States. Nova York: Oxford University Press, 1963.

CHESTERMAN, Simon. Just war or Just peace? Humanitarian intervention and international Law. Nova York: Oxford University Press, 2001.

FABRI, Hélène Ruiz. "Human rights and state sovereignty”. In: ALSTON, Philip e MACDONALD, Euan (orgs.). Human Rights, Intervention and the Use of Force. Nova York: Oxford Univesity Press, 2008

GREWE, Wilhelm G. The Epochs of international law. Nova York: De Gruyter, 2000.

HOLZGREFE, J. L. “The Humanitarian intervention debate”. In: HOLZGREFE, J. L.; KEOHANE, Robert O. (org.). Humanitarian Intervention: ethical, legal and political dilemmas. 5 ed. Cambridge: Cambridge University Press, 2007.

ICISS. The Responsibility to Protect: Report of the International Commission on Intervention 
and State Sovereignty. Toronto. IDRC, 2002.

LUCK, Edward C. "The Responsible Sovereign and the Responsibility to Protect”. In: MÜLLER, Joachim W. e SAUVANT, Karl P. (eds.). Annual Review of United Nations Affairs. Nova York: Oxford University Press, 2008, pp. xxxiii-xliv.

NGUYEN, Quoc Dinh; DAILLIER, Patrick e PELLET, Alain. Direito Internacional Público. 2 ed. Lisboa: Fundação Calouste Gulbekian, 2003.

REZEK, Francisco. Direito Internacional Público. 11 ed. São Paulo: Saraiva, 2003.

TESÓN, Fernando R. “The liberal case for humanitarian intervention”. In: HOLZGREFE, J. L. e KEOHANE, Robert O. Humanitarian intervention: ethical, legal, and political dilemmas. Cambridge: Cambridge University Press, 2003.

WHEELER, Nicholas J. Saving strangers: humanitarian intervention in international society. Nova York: Oxford University Press, 2000.

\section{BIBLIOGRAFIA VIA INTERNET}

ASSEMBLÉIA GERAL DAS NAÇÕES UNIDAS. Resolução 3314 (XXIX) de 14 de dezembro de 1974. Disponível em: http://untreaty.un.org/cod/avl/ha/da/da.html.

THE DUMBARTON OAKS PROPOSALS. Disponível em: http://www.ibiblio.org/pha/policy/1944/441007a.html.

CORTE INTERNACIONAL DE JUSTIÇA - Caso Nicarágua v. Estados Unidos da América. Méritos. 27 de junho de 1986. Disponível em: http://www.icj-cij.org. 